Working Paper No. 97 - October 2012

\title{
THE STAGNATION OF INTERNATIONAL LAW
}

\author{
Joost Pauwelyn \\ Ramsel A. Wessel \\ Jan Wouters
}

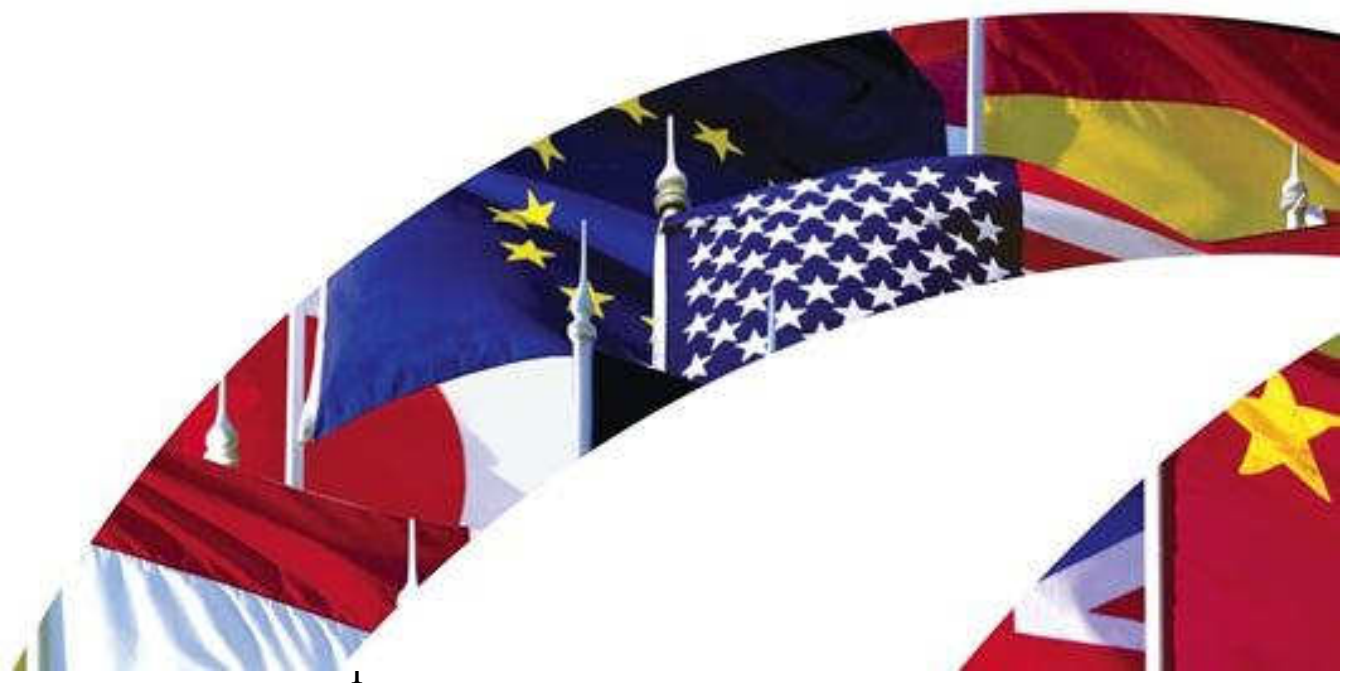




\title{
THE STAGNATION OF INTERNATIONAL LAW
}

\author{
Joost Pauwelyn \\ Ramses A. Wessel \\ Jan Wouters
}

\begin{abstract}
Traditional international law and its instruments are stagnating both in terms of quantity and quality. New, alternative forms of cross-border cooperation, in particular processes of informal international lawmaking, have emerged and gained prominence since the 2000s in response to an increasingly diverse, networked, and knowledge-based society. This transformation impacts on the three axes of actors, processes and outputs in the international legal order. We challenge the assumption that traditional international law is, by definition, legitimate and that this would not be the case for new forms of informal lawmaking: whereas traditional international law is often based on "thin state consent", a "thick stakeholder consensus" underlies many of the new forms of cooperation. It is submitted that the evolution in the international legal order demands an adjustment of models to keep both new forms of cooperation and traditional international law in check. This paper thereto assesses the legitimacy of international legal processes, tackling also the question whether new forms benefit powerful actors and how to keep activity accountable, both domestically and internationally, towards internal and external stakeholders, through ex ante, ongoing and ex post control mechanisms, involving not only managerial or administrative checks and balances but also political and judicial oversight. The paper furthermore examines whether some of the new outputs of international cooperation could already be seen as part of traditional international law and how traditional and new forms are (or could be) interacting before international courts and tribunals. To conclude, a redefinition of the academic discipline of international law to keep both the field and its students sociologically relevant is proposed.
\end{abstract}

\section{KEY WORDS}

International cooperation - Informal international lawmaking - Accountability Legitimacy - Stakeholder consensus - Traditional public international law - Private regulation - Networks - Soft law - History of international law - Definition of law 


\section{AuthORS}

Joost Pauwelyn is Professor of International Law (Graduate Institute of International and Development Studies, Geneva)

Ramses A. Wessel is Professor of the Law of the European Union and other International Organizations (University of Twente)

Jan Wouters is Jean Monnet Chair ad personam, Professor of International Law and International Organizations and Director of the Leuven Centre for Global Governance Studies and Institute for International Law (KU Leuven).

\section{ADDRESS FOR CORRESPONDENCE}

joost.pauwelyn@graduateinstitute.ch ; r.a.wessel@utwente.nl ;

jan.wouters@ggs.kuleuven.be

(C) 2012 by Joost Pauwelyn, Ramses A. Wessel and Jan Wouters. All rights reserved. No portion of this paper may be reproduced without permission of the authors.

Working papers are research materials circulated by their authors for purposes of information and critical discussion. They have not necessarily undergone formal peer review. 


\section{CONTENTS}

1. INTRODUCTION 4

2. EVIDENCE OF THE SLOWDOWN 4

3. REASONS EXPLAINING THE SLOWDOWN 8

A. AN INCREASINGLY DIVERSE NETWORK SOCIETY 10

B. AN INCREASINGLY COMPLEX NETWORK SOCIETY 11

C. WHAT'S NEW? 12

4. OPTIONS IN RESPONSE : MERGER \& ACQUISITION OR ENTRENCHMENT?

5. BACK TO THE FUTURE: THE MALLEABILITY OF THE INTERNATIONAL LEGAL ORDER

6. KEEPING THE NEW AND OLD ACCOUNTABLE

A. ALL COOPERATION THAT AFFECTS FREEDOM - BINDING OR NOT - MUST 18

BE JUSTIFIED

B. COOPERATION OUTSIDE STATE CONSENT CAN BE LEGITIMATE

C. STATE CONSENT IS NOT (LONGER) A SUFFICIENT CONDITION FOR 20 LEGITIMATE COOPERATION

D. DO NEW FORMS OF COOPERATION CIRCUMVENT INTERNATIONAL LAW 20 FORMALITIES?

E. DO NEW FORMS OF COOPERATION CIRCUMVENT LAW FORMALITIES?

F. A CALIBRATED APPROACH TO ACCOUNTABILITY 24

G. NEW FORMS OF COOPERATION AS FIRST-BEST, NORMATIVELY SUPERIOR 25 SOLUTION?

7. POWER AND EXTERNALITIES OR HOW TO TAKE ACCOUNT OF ALL AFFECTED 26 PARTIES

A. POWER REMAINS ASYMMETRIC BUT IS INCREASINGLY DISPERSED 26

B. KEEPING COOPERATION ACCOUNTABLE TOWARD ALL AFFECTED PARTIES 28

C. CREATING THE BEST OF BOTH WORLDS? THICK STAKEHOLDER 30 CONSENSUS RATHER THAN THIN STATE CONSENT

8. THE THRESHOLD OF TRADITIONAL INTERNATIONAL LAW VERSUS THE EMERGENCE 32 OF PROCEDURAL META-NORMS OF ANY RESTRICTION ON FREEDOM
A. THE THRESHOLD FOR A NORM TO BE PART OF TRADITIONAL
INTERNATIONAL LAW
B. THE EMERGENCE OF PROCEDURAL META-NORMS FOR ANY NORMATIVE
RESTRICTION ON FREEDOM
C. A FEW EXAMPLES 


\section{INTRODUCTION}

It is a mantra amongst international lawyers that the field of international law is expanding, exponentially. ${ }^{1}$ This trend, also referred to as the legalization of world politics $^{2}$, may have been true until a decade ago. It is highly questionable today. International law is stagnating both in terms of quantity and quality. Drawing on a two-year research project on "informal international lawmaking" (involving over forty scholars and thirty case studies) ${ }^{3}$, this paper offers evidence in support of the stagnation hypothesis (section 2), evaluates the likely reasons for it (section 3 ) and weighs possible options in response (section 4). It illustrates with a historical account that the international legal order has radically transformed in the past - on all three axes of actors, processes and outputs - so that the conceptual boundaries of how international law may look in the future are wide open (section 5). The article next assesses the legitimacy of both new forms of cooperation and traditional international law (section 6), tackling also the question of whether new forms benefit powerful actors and how to keep activity accountable, both domestically and internationally, toward internal and external stakeholders, through ex ante, ongoing and ex post control mechanisms, involving not only managerial or administrative checks and balances but also political and judicial oversight (section 7). Finally, focusing on the short to medium term, the paper questions whether some of the new outputs of international cooperation could already be seen as part of traditional international law and how traditional and new forms are (or could be) interacting before international courts and tribunals (section 8). In this respect, it proposes certain procedural meta-norms against which new cooperation forms ought to be checked, which we refer to as "thick stakeholder consensus" imposing limits in respect of actors (authority), process and output. Intriguingly, this benchmark may be normatively superior (rather than inferior) to the validation requirements of traditional international law, coined here as "thin state consent". In this sense, international law is stagnating not only in quantity but also quality. Section 9 offers conclusions.

\section{EVIDENCE OF THE SLOWDOWN}

For each decade since the 1950s, the number of new multilateral treaties deposited with the UN Secretary General was around thirty-five. ${ }^{4}$ In the ten years between 2000 and 2010, this number dropped quite dramatically to twenty (in the preceding five decades it had never been below thirty-four). Between 2005 and 2010, only nine

\footnotetext{
${ }^{1}$ See, for example, José Alvarez, The New Treaty Makers, 25 B.C. Int'l \& Comp. L. Rev. 213 (2002) at 216 ("There is little doubt that recent decades have witnessed a striking proliferation in treaties, including multilateral agreements") and Anne Peters, The Growth of International Law between Globalization and the Great Power in 8 Austrian Review of International and European Law (2003) 109-140 at 109 ("International Law is not only growing fast, but is virtually exploding").

${ }^{2}$ J. Goldstein et al. (eds.), Legalization and World Politics (Boston, MIT Press, 2001).

${ }^{3}$ The project was funded by the Hague Institute for the Internationalization of Law (HiiL). See the project website at www.informallaw.org and also Informal International Lawmaking (J. Pauwelyn, R.A. Wessel and J. Wouters, eds.), Oxford University Press, 2012 (hereafter referred to as "OUP book") and Informal International Lawmaking: Case Studies (J. Pauwelyn, R.A. Wessel, J, Wouters, A. Berman and S. Duquet, eds.), TOAEP, 2012 (hereafter referred to as "TOAEP book").

${ }^{4} 36$ in the 1950s; 35 in the 1960s; 36 in the 1970s; 34 in the 1980s and 37 in the 1990s, see UN Treaty Collection, Multilateral Treaties Deposited with the Secretary General (MTDSG, totalling 507 at the time of writing), available at http://treaties.un.org/pages/DB.aspx?path=DB/MTDSG/page1 en.xml\&menu=MTDSG

(counting only new multilateral treaties and not including amendments, protocols or annexes to existing multilateral agreements). Note, of course, that there is no guarantee that all multilateral treaties that have been concluded are also actually deposited with the UN. Yet, these UN numbers do give us a sense of multilateral treaty activity over time.
} 
new multilateral treaties were deposited (in 2011, not a single one). ${ }^{5}$ The broader UN Treaty Series database confirms this downward trend as of the 2000s, both for bilateral treaties (12566 concluded in the 1990s; only 9484 concluded in the 2000s) and multilateral treaties (406 entries in the 1990s; down to 262 in the 2000s). ${ }^{6}$ Looking at individual countries, in the 1990s, 210 treaties were transmitted to the US Senate. In the 2000s, this number was down to $136 .{ }^{7}$ Similarly, the number of international agreements reported to the US Congress under the Case $\mathrm{Act}^{8}$ has fallen significantly and consistently in the last six year, from 313 in 2006 to 288 in 2007, 236 in 2008, 232 in 2009, 197 in 2010 and only 166 in $2011 .{ }^{9}$ In France as well we see a significant dip in the number of treaties reported, by date of signature, from 1152 in the 1990s to 991 in the 2000s. ${ }^{10}$ Most tellingly, the number of multilateral treaties (including such things as protocols, amendments and annexes to existing multilateral treaties, but excluding European treaties) was down from 206 in the 1990 s to only 90 in the 2000s. ${ }^{11}$ The official treaty database of the Netherlands reports a similar decline: from 1427 treaty entries in the 1990s to 1197 in the 2000s. Tellingly, amongst this treaty activity, the number of hits under multilateral treaties is down from 619 to $587 . .^{12}$ Belgium's treaty record displays a similar tendency. ${ }^{13}$

Anecdotally, these numbers make sense. Which is the most recent multilateral treaty that you can think of? The UN database lists the International Cocoa Agreement of June 2010, replacing a similar agreement of 2001. Better known may be the 2003 Framework Convention on Tobacco Control (FCTC). ${ }^{14}$ Yet, subsequent WHO efforts to tackle problems related to diet and alcohol were not enshrined in a formal treaty

${ }^{5}$ Significantly, when looking at five year periods, the numbers are down from 20 (1990-1995)
to 17 (1995-2000), $12(2000-2005)$ and $9(2005-2010)$. When counting not only new
multilateral agreements deposited but all entries into the UN MTDSG database (including
such things as amendments, protocols and annexes) the downward trend as of 2000 is
confirmed: 102 entries in the 1970 s; 99 in the 1980 s; 109 in the 1990 s (the highest number
since recording started); and a decline to 77 in the 2000 s (the lowest number since the
1960 s, when 57 entries were recorded).
6 See UN Series (UNTS) available at http://treaties.un.org/pages/UNTSOnline.aspx?id=1. Multilateral treaties in this database include closed multilateral treaties, multilateral treaties deposited with the UN SG, multilateral not deposited with the UN SG and open multilateral treaties.

7 Numbers are taken from The Library of Congress available at http://thomas.loc.gov/home/treaties/treaties.html.

${ }^{8}$ By statute, 1 U.S.C. $112 \mathrm{~b}(\mathrm{a})$, the US Secretary of State is required to transmit to the US Congress the text of any "international agreement" other than a "treaty" (in the sense of Article II:2 of the US Constitution, that is a treaty to be submitted for approval by $2 / 3$ of the US Senate). Such other "international agreements" are not "treaties" in the US constitutional sense but are legally binding under international law. They include so-called executive agreements and congressional-executive agreements (none of which are adopted by $2 / 3$ of the US Senate). See more on this below in footnote 122

9 Numbers are taken from the US Department of State website available at http://www.state.gov/s///treaty/caseact/.

${ }_{10}$ Numbers are taken from the French government's Base des traités et des accords available at http://basedoc.diplomatie.gouv.fr/Traites/Accords Traites.php.

${ }^{11}$ Since the 1930s, when the total number of multilateral treaties was 65 , this number had never fallen below 135, the number in the 1940s, with a peak of 265 in the 1950s.

${ }_{12}$ Numbers are taken from the official Dutch Verdragenbank available at www.minbuza.nl/producten-en-diensten/verdragen.

13 For the 1990s 813 research results can be found through http://www.ejustice.just.fgov.be/wet/wet.htm whereas for the 2000s only 407 results were found. The picture may be slightly affected by the slower pace of publication of approval laws due to the involvement of a high number of parliamentary assemblies for so-called 'mixed treaties' and the political crisis between 2008-2011.

${ }_{14}$ Adopted by the World Health Assembly in 2003 and in force in 2005, available at http://www.who.int/fctc/en/. 
like the FCTC but rather in non-binding guiding principles part of a Global Strategy on diet $\left(2004^{15}\right)$ and alcohol $\left(2010^{16}\right)$. If anything, what reaches the headlines is the multilateral agreements that fail to be concluded, be it the WTO's Doha Round of trade negotiations (deadlocked for over ten years) or the UNFCCC's attempts to negotiate a successor to the 1997 Kyoto Protocol on climate change. Even in today's most dynamic and studied sub-branch of international law - international investment law - a marked slowdown has taken place in the number of investment treaties concluded since the late 2000s. ${ }^{17}$ Another indication of the tendency away from traditional international lawmaking is the follow-up given to draft texts prepared by the International Law Commission (ILC). Whereas the ILC's work previously resulted often in new multilateral treaties (e.g. the 1969, 1978, 1983 and 1986 Vienna Conventions on treaty law) the most recent time this happened was the 2004 UN Convention on Jurisdictional Immunities of States and their Property, following the ILC's 1991 draft articles on this matter.

Policy preferences expressed by a number of states confirm the stagnation hypothesis and are likely to further strengthen it in the future. In Germany, for example, federal ministries are instructed, "before international law treaties ... are elaborated on and concluded", to "check whether a binding contract under international law is irrefutable or whether the same goal may also be attained through other means, especially through understandings which are below the threshold of an international agreement". ${ }^{18}$ Similarly, Canada's policy is that "if a matter is of a routine or technical nature, or appears to fall entirely within the existing mandate and responsibility of a department or agency, and if it does not contain substantive matter which should be legally binding in public international law, it is often preferable to deal with the matter through the use of a non-legally binding instrument". ${ }^{19}$ The 2010 US National Security Strategy, in turn, refers to the "shortcomings of international institutions that were developed to deal with the challenges of an earlier time" and calls on US authorities "to spur and harness a new diversity of instruments, alliances, and institutions". ${ }^{20}$

Some may object that the picture outlined above fails to take into account other dynamics of international law, such as the continuing evolution of customary international law, the on-going activity of international organizations and the steady production of case law by international courts and tribunals. As to customary law,

${ }^{15}$ Global Strategy on Diet, Physical Activity and Health, adopted by the World Health Assembly in 2004, available at http://www.who.int/dietphysicalactivity/en/.

${ }^{16}$ Global Strategy to Reduce the Harmful Use of Alcohol, adopted by the World Health Assembly in 2010, available at http://www.who.int/substance_abuse/activities/globalstrategy/en/.

17 See A. Aaken, 'The International Investment Protection Regime through the Lens of Economic Theory,' in: The Backlash Against Investment Arbitration, Waibel, Kaushal, Chung and Balchin (eds.), Chapter 23; S. Jandhyala, W. Henisz, and E. Mansfield, 'Three Waves of BITs: The Global Diffusion of Foreign Investment Policy,' 55 Journal of Conflict Resolution (2011) 1047-1073.

18 Bundesregierung, Gemeinsame Geschäftsordnung der Bundesministerien (2009) $<$ http://www.bmi.bund.de/cae/servlet/contentblob/139852/publicationFile/55730/ggo.pdf. $>$ accessed 26.10.2011. Author's translation. The original text reads: ,Vor der Ausarbeitung und dem Abschluss völkerrechtlicher Verträge (Staatsverträge, Regierungsübereinkünfte, Ressortabkommen, Noten- und Briefwechsel) hat das federführende Bundesministerium stets zu prüfen, ob eine völkervertragliche Regelung unabweisbar ist oder ob der verfolgte Zweck auch mit anderen Mitteln erreicht werden kann, insbesondere auch mit Absprachen unterhalb der Schwelle eines völkerrechtlichen Vertrags.'

${ }^{19}$ Canada Treaty Information, 'Policy on Tabling of Treaties in Parliament' (2011), Annex C $<w w w . t r e a t y-a c c o r d . g c . c a / p r o c e d u r e . a s p>$.

20 US National Security Strategy, 27 May 2010, available at http://www.whitehouse.gov/sites/default/files/rss viewer/national security strategy.pdf 
although we agree that intensified international interaction may lead to a more rapid formation of customary rules in specific instances ${ }^{21}$, today's preference of States for non-binding arrangements obviously also impacts upon customary law, as the essence of the latter's opinio juris component relates precisely to the legally binding character of an obligation. ${ }^{22}$ Moreover, with fewer multilateral conventions generated it becomes harder to find strong evidence of opinio juris confirmed by practice. ${ }^{23}$ As to the output of international organizations, although they obviously continue to function and produce plenty of resolutions, statements and decisions, many of the normative instruments they recently produced or endorsed are legally non-binding, such as the Guidelines for Implementation of the FCTC. ${ }^{24}$ Moreover, many of the classical multilateral institutions currently face serious challenges, from deep divisions at the UN Security Council ${ }^{25}$ to immobilism at the WTO ${ }^{26}$, severe budget cuts or even membership dropout in a variety of organizations ${ }^{27}$ and difficult reform

${ }^{21}$ See e.g. with an emphasis on the significance of certain General Assembly resolutions
during times of fundamental change, M.P. Scharf, Seizing the 'Grotian Moment': Accelerated
Formation of Customary International Law in Times of Fundamental Change, 43 Cornell
International Law Journal (2011), 439 .
${ }_{22}$ See inter alia ICJ, Case concerning military and paramilitary activities in and against Nicaragua - Merits (Nicaragua / United States), judgment of 27 June 1986, I.C.J. Rep. 1986, 14, para. 188. Cf. Jutta Brunnée, book review 'Precautionary Legal Duties and Principles in Modern International Environmental Law, by H. Hohmann', 33 Canadian Yearbook of International Law (1996), 484, at 487.

${ }^{23}$ Ibid., para. 183; Continental Shelf (Libyan Arab Jamahiriya/Malta), I.C.J. Rep. 1985, p. 13, para. 27, as recently confirmed in Jurisdictional Immunities of the State (Germany/ltaly: Greece Intervening), para. 55.

${ }^{24}$ See, for example, José Alvarez, International Organizations as Law-Makers (Oxford University Press, 2005); Jonathan G.S. Koppell, World Rule. Accountability, Legitimacy, and the Design of Global Governance (The University of Chicago Press, 2010).

${ }^{25}$ Illustrative of those divisions are the three recent joint vetoes expressed by Russia and China on draft UN Security Council resolutions regarding Syria, respectively on 4 October 2011, 4 February 2012 and 19 July 2012. Interestingly, this has led to a remarkable resolution of the UN General Assembly adopted on 3 August 2012, A/RES/66/253, overtly criticizing the Security Council for its failure to take action on the Syria crisis.

${ }^{26}$ See inter alia Joost Pauwelyn, The WTO in Crisis: Five Fundamentals Reconsidered, WTO Public Forum, September 2012, at http://www.wto.org/english/forums e/public forum12 e/art pf12 e/article e.htm?art=9;

Mehdi Abbas, De Doha à Cancún: éléments d'analyse de la crise du multilatéralisme commerciale et de l'organisation mondiale du commerce, 6 Annuaire Français des Relations Internationales (2005), 880-900.

${ }^{27}$ The 2008 financial crisis has led to severe cuts in membership contributions to a variety of organizations. See, for example, as to the 2012-2013 budget of the Council of Europe: 'The Programme and Budget 2012-2013 is geared towards a strict control of expenditure, including significant reductions in staff and the redeployment of resources to priority sectors in the area of Human Rights, Rule of Law and Democracy with greater emphasis on field activities and the effectiveness of the monitoring mechanisms to achieve better co-ordination of activities, increased efficiency and higher impact' (available at http://www.coe.int/aboutcoe/index.asp?page=budget). As to the UN, in its Resolution A/RES/66/248 of 24 December 2011 the UN General Assembly for the first time in 50 years decided to reduce the biannual (2012-2013) budget of the UN with $5 \%$, in spite of the continued new demands upon the organization. Governments have recently also conducted critical reviews of the added value of the work of multilateral organizations, especially in the global development effort: see inter alia Australian Government/Australian AID, Australian Multilateral Assessment (March 2012); DFID, Multilateral Aid Review. Taking Forward the Findings of the UK Multilateral Aid Review (March 2011); Adrien Gouteyron, Rapport d'information fait au nom de la commission des finances sur les contributions financières de la France aux organisations internationales, Sénat, No 390, 2010-2011; Ministerie van Buitenlandse Zaken, Samenwerken aan mondiale uitdagingen. Nederland en multilaterale ontwikkelingssamenwerking (April 2009). 
processes. ${ }^{28}$ Unlike the post-cold war enthusiasm of the 1990 s there is a rather broad acknowledgment that traditional forms of multilateralism are facing a deep crisis. It is partly because of the dissatisfaction with the rigidities and inadequacies of classical international institutions that governments have turned to informal cooperative fora, from the Kimberley Scheme to the G-20. Although international courts and tribunals continue their steady output, they mainly contribute - as they should - to the interpretation and clarification of existing international law rather than to developing new legal norms and principles. ${ }^{29}$ Moreover, most of these (quasi-) judicial bodies were set up in the late twentieth century. No new international court with broad jurisdiction has been conceived in the twenty-first century. ${ }^{30}$

\section{REASONS EXPLAINING THE SLOWDOWN}

Is the stagnation of international law due to fewer cross-border contacts or problems? We doubt it. If anything, interdependence continues to increase. Some of the slowdown may be explained by the fact that treaties now exist on many of the major questions. Yet, most of the numbers above also include updates or amendments to existing treaties and also those numbers are down. In addition, new matters continue to arise so that, at least in the five decades from 1950 to 2000, the number of new treaties has followed an upward trend. Is it because interests increasingly diverge so that finding solutions becomes more difficult? Some of this is certainly happening and we will return to it. Yet, it does not explain the basic paradigm shift. Whereas treaties and international law stagnate, a rich tapestry of novel forms of cooperation, ostensibly outside international law, is thriving. It is not that cross-border agreement can no longer be found. It is simply that it takes different forms and involves a different constellation of actors and processes, outside the traditional confines of international law. The nomenclature used is increasingly diverse and creative, everything but the formal terms treaty, agreement or international organization. Instead, we have witnessed the creation of the International Conference on Harmonization (in respect of registration of pharmaceuticals), the Wassenaar Arrangement on export controls of conventional arms, the Kimberley Scheme on conflict diamonds, the Proliferation Security Initiative $^{31}$, the International Competition Network, the Copenhagen Accord on climate change, the ISO 26000 Standard on social responsibility, the Group of 20 (G$20)$, the Financial Stability Board, the Ruggie Guiding Principles on Business and

\footnotetext{
${ }^{28}$ E.g. the ever-ongoing talks on the reform of the UN Security Council: see inter alia Yehuda Z. Blum, Proposals for UN Security Council Reform, 99 American Journal of International Law (2005), 632-649; Shashi Tharoor, Security Council Reform: Past, Present, and Future, 25 Ethics and International Affairs (2011), 397-406; Jan Wouters and Tom Ruys, Security Council Reform: a New Veto for a New Century? 44 Revue de Droit Militaire et de Droit de la Guerre (2005), 139-174; or the slow implementation of the reform of the IMF decided by the G20 in 2010 in order to accommodate the BRIC countries: G20, 'Communiqué Meeting of Finance Ministers and Central Bank Governors', Gyeongju, Republic of Korea, 23 October 2010, par. 5, http://www.g20.utoronto.ca/2010/g20finance101023.html.

${ }_{29}$ See, however, as to the impact of the case law of international criminal tribunals on customary international law and on domestic legal systems, Roozbeh B. Baker, Customary International Law in the $21^{\text {st }}$ Century: Old Challenges and New Debates, 21 European Journal of International Law (2010), 173.

${ }_{30}$ Admittedly, the UN Security Council set up an ad hoc international criminal tribunal with very circumscribed jurisdiction to handle the killing of Lebanon's former prime minister Rafiq Hariri with UNSC Res 1757 of 30 May 2007.

${ }^{31}$ John Yoo and Glenn Sulmasy, 'The Proliferation Security Initiative: a model for international cooperation', 35 Hofstra L. Rev. (2004) 405.
} 
Human Rights ${ }^{32}$, the Internet Engineering Task Force, the Global Strategy on Diet, and the list goes on. ${ }^{33}$

Manifestly, a lot was worked out or agreed on in the last decade. Only, much of it was set out in new forms and new processes outside both traditional international law and traditional international organizations. As Jim Leape, Director General of WWF International, put it on his return from what many regard as a failed Rio+20 Conference in June 2012: "It's Happening, but Not in Rio". ${ }^{34}$ Jan Klabbers goes as far as stating that "[g]lobalization seems to have bypassed the discipline of international law completely" ${ }^{35}$ Willke points at "a dramatic tension between the postmodern dynamic of globalization and a pre-modern state of global decisionmaking". ${ }^{36}$ What explains this trend, which we have referred to elsewhere as the rise of "informal" international lawmaking (IN-LAW) ${ }^{37}$ ? In our view, it is deep societal changes that are not unique to international law but affect both international and national legal systems. ${ }^{38}$ In the United States, for example, the number of formal Food and Drug Administration (FDA) regulations adopted each year in accordance with the Administrative Procedure Act (APA) rulemaking procedures declined dramatically since the mid 1990s. By contrast, in the same period, there has been a striking increase in the number of FDA-issued documents intended to give guidance

${ }^{32}$ See Business and Human Rights at a Crossroads: the Legacy of John Ruggie (R. Mares, editor) (Martinus Nijhoff, Leiden and Boston, 2011); K. Buhmann, 78 Nordic Journal of International Law (2009) 1-52.

${ }^{33}$ Whereas the stagnation of treaty activity can be empirically demonstrated (based, at least, on what states report, see above), the rise in these informal or non-traditional forms of cooperation is more difficult to document. By their nature and informal character, actors involved (including public authorities) often do not report them (a problem we return to below). It is therefore extremely difficult, if not impossible, to determine the universe of this activity or to say with certainty that it has increased in the last decade or two. That said, anecdotal evidence and the empirical research we were able to conduct, including over thirty case studies (see www.informallaw.org), confirms their rise, in particular since the late 1990s. On top of the examples listed above see e.g. the International Strategy for Disaster Reduction (1999), the World Anti-Doping Agency (1999), the Andean Committee for the Defence of Competition (2005), the Central American Group of Competition (2006), the UN Principles for Responsible Investment (2006), the International Forum of Sovereign Wealth Funds (2009), the Global Network Initiative (2008, see http://www.globalnetworkinitiative.org), the International Medical Device Regulators Forum (2011). Many of these are discussed in the OUP and TOAEP books supra note 1.

${ }^{34}$ New York Times, 24 June 2012 ("The text finally agreed upon here in Rio is a passing description of 'the future we want,' but it does not set us on the path to get there. Yet there is hope. If you looked around in Rio last week, you saw where the action really is - local and national governments, companies, NGOs, labor unions finding ways to get on with it").

${ }^{35}$ Jan Klabbers, The Idea(s) of International Law, in The Law of the Future and the Future of Law (eds. Muller, Zouridis, Frishman and Kistemaker, 2011), 69 at 71.

${ }^{36}$ Helmut Willke, Governance In A Disenchanted World, The End Of Moral Society (2009) at 6 (referring to "a world society which is lacking institutions of central political decision-making - and is substituting this deficiency with considerable capacities of self-organization and decentralized governance").

${ }_{37}$ We defined "informal international lawmaking ( (IN-LAW) as follows: "Cross-border cooperation between public authorities, with or without the participation of private actors and/or international organisations, in a forum other than a traditional international organisation (process informality), and/or as between actors other than traditional diplomatic actors (such as regulators or agencies) (actor informality) and/or which does not result in a formal treaty or other traditional source of international law (output informality)" (Pauwelyn, Chapter 1, OUP book).

${ }^{38}$ On the emergence of new actors and forms in domestic legal systems see Eberhard Bohne, Der informale Rechtsstaat (Duncker \& Humblot, Berlin 1981) and Flückiger, chapter 19 in OUP book. 
to the regulated industry but not adopted through public procedures. ${ }^{39}$ Also within the European Union (EU) informal cooperation and the establishment of agencies have increased considerably since the 2000s. ${ }^{40}$ The societal undercurrents explaining this trend toward "informality" involving new actors, new processes and new outputs referred to below as the emergence of an increasingly diverse and complex network/knowledge society - go far beyond the traditional, functional explanations for informal cooperation or "soft law" conventionally discussed in the literature (e.g. the relative costs and benefits related to formal versus informal agreements) ${ }^{41}$

\section{a. An increasingly diverse network society}

Firstly, we are witnessing a move from societies of individuals (at the national level) and a society of territorial states (at the international level) to an increasingly transnational society of networks. ${ }^{42}$ These networks both disaggregate the state and transcend the state. Within states, new internationally active actors have emerged which cooperate with their counterparts across borders, be they industry or sector specific regulators, competition authorities, central banks, provinces or cities, judges or parliaments. Beyond states, new actors have converged not on national, let alone sub-national interests of the nation state, but on economic or societal interests that span across territories, be it transnational corporations whose fortunes are spread across the globe, single-issue, global NGOs (think of Amnesty International or Médecins sans Fontières) or international coalitions of consumers, farmers, workers or other special interests or citizen groups.

On top of that also the number of states themselves has increased and, more importantly, the power differences between some of them have flattened. Whereas the cold war period pitted two blocks against each other (with a Third World rising in the background), the specter of sole US hegemony did not outlive the 1990s for long. Most characteristic of the 2000s is the emergence of new powers such as China, Brazil, India and South Africa, each pulling more weight around, making firmer claims and seeking their own interests (economic, political and ideological). This diversity has given rise to new clashes and divisions and has not made consentbased solutions easier on topics ranging from trade and climate change to finance,

39 See John C. Carey, The FDA's Policymaking Quandary: Is Guidance Reform an Appropriate Solution (1997) (unpublished work), quoted in Todd D. Rakoff, The Choice Between Formal and Informal Modes of Administrative Regulation 52 Administrative Law Review (2000) 159.

${ }^{40}$ See Vos, chapter 17 in OUP book, D. Geradin, N. Petit and R. Munoz (eds) Regulation through Agencies: A New Paradigm for EC Governance (Edward Elgar, Cheltenham 2005) and M. Busuioc, The Accountability of European Agencies, Legal Provisions and Ongoing Practices (Eburon, Delft 2010).

${ }^{41}$ See Anthony Aust, The Theory and Practice of Informal International Instruments, 35 ICLQ 1986, 787-812; Charles Lipson, Why Are Some International Agreements Informal?, 45 International Organization 1991, 495-538.

${ }^{42}$ Anne-Marie Slaughter, A New World Order, Princeton University Press, 2004. KENNETH W. ABBOTT AND DUNCAN SNIDAL, Strengthening International Regulation Through Transnational New Governance, 42 Vanderbilt Journal of Transnational Law (2009). 
human rights, access to raw materials and energy. ${ }^{43}$ At the same time, it has also created and enabled new alliances and networks such as the BRICS ${ }^{44}$ and G-20.

This diverse network society has given rise to new actors and new forms or processes of cooperation, other than those traditionally recognized by international law. ${ }^{45}$ The state remains a pivotal entity of interest aggregation, legitimation and control. Yet, it is supplemented, assisted, corrected and continuously challenged by a variety of other actors be they regulators, national and international agencies, city mayors, businesses or NGOs who can make cooperation not only more legitimate but also more effective.

\section{b. An increasingly complex knowledge society}

Secondly, besides the actors and processes driving the interactions, also the output or type of cooperation emerging, and the forces that can legitimize it, have changed and diversified. It used to be carefully negotiated but subsequently relatively stable treaties consented to by states - or resolutions issued by international organizations (IOs) set up by those same states - on the assumption that state representatives most legitimately represent the people. In an increasingly complex society complexity at all levels, political, technological, scientific, regulatory etc. - authority flows from other sources too, both public and private ${ }^{46}$, in particular, expertise or knowledge or acceptance by affected stakeholders within or outside the polity that enacts a particular norm or regulation. ${ }^{47}$ In addition, complexity and the resulting uncertainty and rapid change that comes with it, requires more flexible norms or guidelines, grounded in practical experience and expertise and continuously corrected to take account of new developments and learning. ${ }^{48}$ As Scott observes, in the context of financial norms emanating from the Basel Committee, '[i]t appears that

\footnotetext{
${ }^{43}$ According to Susan Schwab (former USTR), for example, "the central question facing international economic governance today" is: "What are the relative roles and responsibilities of advanced (or developed), emerging, and developing countries"? Not addressing this central question (and the continuing "lumping together of all emerging and developing economies") is, in her view, the core reason for the Doha Round's failure (Susan Schwab, After Doha, Why the Negotiations are Doomed and What We Should do About it, 90 Foreign Affairs (2011) 104 at 105 and 111).

${ }^{44}$ For the possible impact thereof on the evolution of international law and international organizations, see inter alia Paulo Borba Casella, BRIC - Brésil, Russie, Inde, Chine et Afrique du Sud: à l'heure d'un nouvel ordre juridique international (Paris, Pedone, 2011); Stephan Keukeleire and Hans Bruyninckx. The European Union, the BRICs, and the Emerging New World Order, in Christopher Hill and Michael Smith (eds), International Relations and the European Union (OUP, 2008), 380.

${ }^{45}$ The argument has been made that some of these new powers (e.g. China) have an inherent preference for more informal modes of cooperation. To the extent this is correct, the stagnation of international law may go hand in hand with the rise of these new powers. See Suami, Chapter 2, TOAEP book ("unlike in other regions including Europe, there are fewer ordinary international organizations in East Asia") and Miles Kahler, Legalisation as Strategy: The Asia-Pacific Case, in Legalisation and World Politics, 165-167 (Judith L. Goldstein, Miles O. Kahler, Robert Keohane and Anne-Marie Slaughter eds. 2001).

${ }^{46}$ Harm Schepel, The Constitution of Private Governance: Product Standards in the Regulation of Integrating Markets, Hart Publishing, 2005.

${ }^{47}$ Helmut Willke, Smart Governance, Governing the Global Knowledge Society, Campus, 2007.

${ }_{48}$ As Willke supra note 36 puts it (at 33), "knowledge and expertise are provisional by necessity. They exist to be revised. Even worse, transitions and revisions are not steps in the approximation to a final truth but remain provisional steps in a never-ending story".
} 
Basel II may be more like Basel 2.0 (in software language) to be continuously updated by later "releases". 49

Binding treaties or $1 \mathrm{O}$ decisions based on one-off and increasingly thin or derivative state consent are being replaced or supplemented by practice norms or standards based on continuous (and increasingly thick or direct) stakeholder consensus. ${ }^{50}$

In sum, the societal undercurrents described above - essentially, the emergence of an increasingly diverse and complex network/knowledge society - is transforming the actors, processes and outputs at work or required to deliver international cooperation. The actors (central state authorities), processes (formal lawmaking in IOs) and outputs (rigid treaties or IO decisions) recognized in traditional international law are not adapted. That is what explains the stagnation of international law. INLAW or new forms of transnational cooperation are, in most cases, chosen not as part of some dark conspiracy to avoid legal constraints or to create an end-run on democracy. In many cases, they develop out of technical necessity ${ }^{51}$, e.g. because the actors involved cannot legally or technically conclude a treaty (be it because of limits under domestic or international law) or because a treaty would simply not be appropriate to the circumstances, e.g. a rapidly changing field with a lot of uncertainty, and a multitude of essential actors beyond central States, where adaptable, practice-based norms are needed which require continuous feedback and correction in the face of new developments.

\section{c. What's new?}

Many of these developments, considered in isolation, are not particularly new and have accrued, with ups and downs, over time. The emergence of new actors (in particular, individuals, transnational corporations and civil society) has been discussed for decades. Some are fairly old: an NGO like Anti-Slavery International finds its roots in the British and Foreign Anti-Slavery Society created in 1839, and the International Committee of the Red Cross (ICRC) was created in 1863. More recently proliferating is the cross-border activity of regulators and administrators part of the disaggregated state described above. Similarly, alternative forms of output other than treaty or custom, such as standards or guidelines or non-binding recommendations of IOs are not new: the ISO was created in 1947; the ILO with its tripartite structure of governments, employers and workers in 1919; non-binding or informal gentlemen agreements have been around for ever ${ }^{52}$, and debates on international "soft law" have raged since the 1970s when newly independent states sought to instrumentalize, in particular, UN General Assembly resolutions. ${ }^{53}$ Formal international organizations as we know them today (such as the UN, OECD or WTO) are actually relatively new and post-date $19^{\text {th }}$ century transnational administrative unions, congresses or commissions similar to some of the "new" cooperation forms we witness today (think of the International Telegraph Union or the Universal Postal

$49 \mathrm{Hal}$ S Scott, International Finance: Transactions, Policy, and Regulation (15 ${ }^{\text {th }}$ edn Foundation Press, New York 2008) 347.

${ }^{50}$ G. P. Callies and P. Zumbansen, Rough Consensus and Running Code: A Theory of Transnational Private Law, Hart Publishing 2010.

${ }^{51}$ See M. Hartwich, ICANN - Governance by Technical Necessity, in Bogdandy et al, supra note 131131.

52 See Jules Basdevant, 'La conclusion et la redaction des traités et des instruments diplomatiques autres que les traités' (1926) 15 Recueil des Cours V, 539-643 and Pierre Michel Eisemann, 'Le gentlemen's agreement comme source du droit international' (1979) 106 Journal du Droit International, 326-348.

${ }^{53}$ See, for example, Bruno Simma, Völkerrecht in der Krise, 20 Oesterreichische Zeitschrift für Aussenpolitik (1980) 280. 
Union created in, respectively, 1865 and 1874). ${ }^{54}$ The stagnation of international law goes beyond the individual and separable phenomena of soft law, new centers of public and private authority or global administrative law. The network/knowledge society described above has accentuated all of these individual currents and is now bundling and encapsulating them into one major, new transformation that simultaneously propels the importance of IN-LAW and risks bringing traditional international law to a halt. The stagnation described here goes beyond the phenomenon of soft law as it addresses not only informal output but also new and informal actors and processes. Moreover, even in terms of output, there is nothing "soft", i.e. vague, aspirational or deeply contested (in the sense of UN General Assembly resolutions of the 1970s) about most of the internet, medical devices or financial norms developed in recent years. If anything, the process of their development is highly regulated and strict, based on consensus, and the expectation as to compliance with these norms is extremely high (higher than in respect of many traditional treaties). What characterizes these finance, medical devices or internet norms is not so much that they are non-binding under international law (the hallmark of "soft law") but rather that they are outside traditional international law altogether. Similarly, the stagnation of international law described here goes beyond "global administrative law". There is nothing "administrative" about the G-20, after all, a meeting of heads of state at the highest political level. Yet, the G-20 and its communiqués epitomize the stagnation of traditional international law and international organizations. Nor do we consider that the solution to this stagnation is "administrative". As discussed below, it goes beyond managerialism and requires both politics and courts. Put differently, the phenomenon described here may include but goes beyond both "soft law" and "global administrative law".

It is, indeed, the combined proliferation of three phenomena - new actors, new outputs and new processes - and the concurrent slowdown in traditional international law that is new, in particular since the late 1990s. Until recently, for example, NGOs (or transnational corporations, for that matter) sought to achieve their international regulatory ambitions by acting (mainly) through the state-centric system of traditional international law, for example, by pushing (or blocking) certain points on the UN or WTO agenda or getting states to agree on a treaty, be it the convention against land mines, the Rome Statute on the International Criminal Court or the TRIPS agreement. More recently, however, NGOs (and business alike) increasingly develop norms outside these confines and steer behaviour more directly (and, in many cases, more effectively) through private coalitions or public-private partnerships (think of the Roundtable on Sustainable Biofuels, ICANN or the International Code of Conduct for Private Security Service Providers). The 1990s may represent the apex of formal and legalized international law and organization: end of the cold world; reactivation of the UN Security Council; 1992 Rio Conference; entry into force of the Law of the Sea Convention, creation of the WTO and the Energy Charter Treaty in 1994; unlimited extension in time of the Nuclear NonProliferation Treaty in 1995; 1997 Kyoto Protocol; 1998 ICC Rome Statute. ${ }^{55}$ The turn of the century, in contrast, represents a breaking point.

\footnotetext{
${ }^{54}$ See Christian Tietje, History of Transnational Administrative Networks, in Transnational Administrative Rule-Making, Performance, Legal Effects, and Legitimacy (O. Dilling, M. Herberb and G. Winter, eds, 2011), 23-38.

${ }^{55}$ This flurry of treaty-making and setting up of new international tribunals in the 1990s may historically be matched only by the post World War I League of Nations years. Describing this period (1919-1940) Grewe (Wilhelm G. Grewe, The Epochs of International Law, Translated and revised by Michael Byers, W. de Gruyter, 2000) refers to "a frenzy of law-making" (at 603), "an exuberance of codification attempts and overflow of norm creation" (at 606) concluding that "[i]n no other period of the history of international law have so many attempts at codification been undertaken and such a wealth of legal norms been created in such a limited space of time. However, the weight of these achievements was inversely related to
} 


\section{OPTIONS in RESPONSE: MERgER \& ACQUisition OR ENTRENCHMENT?}

Logically speaking, two options present themselves. First, international law can adapt and incorporate (at least part) of the new activity described above, thereby increasing its societal relevance (merger and acquisition).$^{56}$ Second, international law can entrench itself and stick to its traditional typologies, acknowledging that it is increasingly just one form of international cooperation (mainly for states) within a broader "legal universe" or "normative menu" of options from which actors can choose. $^{57}$ The second option (entrenchment) must not mean the disappearance of international law. In the title of this paper we deliberately use the word stagnation, not fall or demise, of international law. Existing treaties, international organizations and courts and tribunals will continue to play pivotal roles (be it the UN Security Council, the International Criminal Court or the WTO) and new treaties will be created, albeit at a slower pace and especially in traditional fields (such as extradition or mutual assistance in criminal matters, taxation and trade) or treaties where states give rights to individuals (such as human rights or investment treaties). Under the second option, the core question would then be how traditional international law interacts with other forms or items on the available "normative menu". The first option (merger and acquisition), in contrast, would require a radical transformation of international law, both procedurally and substantively. Sudden and deliberate change is unlikely. Since the system is largely controlled by states, it is unlikely that these same states will formally agree to end their quasi-monopoly and accept sources of international law that are completely out of their sphere of influence. At the same time, traditional international law is anything but formalistic and does allow for organic change to reflect new social realities. ${ }^{58}$ In terms of actors, although states are currently the principal subjects and creators of international law, there is no fixed list of subjects of international law that is set in stone. ${ }^{59}$ Based on practice and recognition new subjects and creators of law may and have emerged or disappeared (see the next section below) ${ }^{60}$ In terms of output, there is general

their scope and the expense invested in them" (at 606). It is perhaps that latter, qualitative aspect that distinguishes the 1990s from the League of Nations period.

${ }^{56}$ See Paul Schiff Berman A Pluralist Approach to International Law, 32 Yale J. Int'I L. 301 (2007) (referring to "multiple normative communities, some of which impose their norms through officially sanctioned coercive force and formal legal processes, but many of which do not" and adding that "it has become clear that ignoring such normative assertions altogether as somehow not "law" is not a useful strategy").

${ }^{57}$ For an early realization of this, see Michel Virally, 'La distinction entre textes internationaux de portée juridique et textes internationaux dépourvus de portée juridique (à l'exception des textes émanant des organisations internationales)' (1983/) 60 Annuaire de l'Institut de Droit International I, 166-257.

${ }^{58}$ For evidence of change and creativity at international organizations, see Gabrielle Marceau, IGOs in Crisis? Or New Opportunities to Demonstrate Responsibility? 8 International Organizations Law Review (2011) 1-13.

${ }^{59}$ See Jean d'Aspremont, Formalism and the Sources of International Law, OUP, 2011 at 14. For a description of subjects of international law currently accepted, see Walter, 'Subjects of International Law', Section B.

${ }^{60}$ See the Reparations case (at 174), where the ICJ held that "throughout its history, the development of international law has been influenced by the requirements of international life [and that] the progressive increase in the collective activities of States has already given rise to instances of action upon the international plane by certain entities which are not States. [...] Such new subjects of international law need not necessarily be States or possess the rights and obligations of statehood". See also Hersch Lauterpracht who has pointed out that it is important...to bear in mind that the range of subjects of international law is not rigidly and immutably circumscribed by any definition of the nature of international law but is capable of modification and development in accordance with the will of States and the requirements of international intercourse.' (Hersch Lauterpacht, 'The Subjects of International Law' in E. Lauterpacht (ed.) International Law, The Collected Papers of Hersch Lauterpacht, Volume I: The General Works (Cambridge University Press, Cambridge 1970), para. 48. 
agreement that Article 38 of the ICJ Statute does not offer an exhaustive list of the sources of international law ${ }^{61}$, nor does international law require that a particular process be followed to create international norms or that international law can only emerge out of particular fora or international organizations. As a result, new sources and processes can and have emerged (such as unilateral acts, including decisions by international organisations) and even explicitly provided for sources and their lawascertainment criteria remain vague ${ }^{62}$ and can be adapted to new developments. The constituent elements of custom and general principals are notoriously vague. Even the definition of what is a convention or treaty is contested and open to interpretation. ${ }^{63}$ Hence, even though it is hard to imagine, for example, that the state parties to the ICJ Statute amend Article 38 to expand the sources of international law, or that the UN Charter be re-written to explicitly allow for new actors, no such formal decisions are required for international law to evolve. Vetoes or deadlocks at the UN, IMF or WTO are no roadblocks to underlying changes in international law. Notwithstanding deadlock on admitting new observers in the WTO, NGOs do not require the WTO's blessing to engage in norm activity on, for example, trade and sustainable energy. ${ }^{64}$ Whether or not states (or IOs) like it, or explicitly allow for it, new actors, processes and outputs are and will continue to play an increasing role. The first battle ground is more likely to be international courts and tribunals. It is there that the line and interaction between traditional international law and new forms of cooperation will be tested and contested. Some will undoubtedly close their eyes to new developments ${ }^{65}$, others will engage. ${ }^{66}$ Yet, also international courts and tribunals will be unable to stop change. After all, whether new modes of cooperation will have an impact or persist will play out not so much at the UN or WTO, or before courts or tribunals, but in foreign ministries, national parliaments and regulatory bodies, standard-setting and procurement organizations, corporate board rooms and rating agencies, NGO or trade union strategy meetings, the media and individual citizen/consumer decisions. Only a fraction of traditional international law is made or plays out before courts or tribunals. The same is true all the more for new forms of cooperation.

\section{BACK to the Future: The Malleability Of the INTERNATIONAL LEGAL ORDER}

To grasp the contours of possible transformation, and how radical it can be (at least conceptually), it may be as helpful to look back in time as it is to speculate about the future. International lawyers, like many specialists deeply engrossed in their field, perceive the present pillars and structure of international law - only states and state

\footnotetext{
${ }^{61}$ See O. Spierman, International legal argument in the Permanent Court of International Justice, CUP, 2005 at 207 (with references to authors and negotiation documents).

${ }^{62}$ As d'Aspremont supra note 59 at 151 puts it, the "sources of international legal rules do not rest on any formal law-ascertainment mechanisms, for these rules are not identified on the basis of formal criteria ».

63 The Vienna Convention on the Law of Treaties defines "treaty" as "an international agreement concluded between States in written form and governed by international law" (Article 2:1(a)). This, of course, begs the question of what an "international agreement" is and when such agreement can be said to be "governed by international law". In addition, the Vienna Convention (in Article 3) explicitly acknowledges that there are other international agreements part of international law but outside the scope of the Vienna Convention, in particular, (i) "international agreements concluded between States and other subjects of international law" (whatever these other subjects may be), (ii) international agreements "between such other subjects of international law", and (iii) "international agreements not in written form". See Jan Klabbers, The Concept of Treaty in International Law, Kluwer, The Hague, 1996.

${ }^{64}$ See, for example, the Sustainable Energy Trade Agreement proposed by a coalition of countries and NGOs, discussed at http://ictsd.org/i/news/bridgesweekly/115745/.

${ }^{65}$ See infra note 202, Mauritius v. UK arbitration under UNCLOS.

${ }^{66}$ See infra note 193, WTO panel report on US - Tuna II.
} 
consent can create international law; only treaties and custom are sources of international law - as firmly established since time immemorial and to be protected as written in stone for based on practice and theory elaborated, tested and confirmed over centuries.

In the field of international law, as in many other fields, nothing could be further from the truth. The very term "international law" was introduced as recently as 1789 by Jeremy Bentham. ${ }^{67}$ Among continental European scholars the term "European law of nations" (Europäisches Völkerrecht), not "international law", was used until the 1880s (telling us something about the then recognized actors of international law, that is, essentially European states). ${ }^{68}$ Indeed, it is generally accepted that modern international law or post-classical international law, as we know it today, began to evolve in 1919 , that is, less than a century ago. ${ }^{69}$ So what may seem firmly embedded today and unimaginable to change any time in the future, is actually of pretty recent vintage.

It suffices to read history to realize that an international legal order - or what we referred to above as "legal universe" or "normative menu" - can also present itself differently and radically evolve over time including at the three core levels of actors, forms and processes identified earlier. Making abstraction of the concept of states, there are, indeed, only two minimum prerequisites for an international legal order to exist: (i) a set of relatively independent actors, not subject to a superimposed power which are, nonetheless, (ii) linked in their relationships through norms which are accepted as constraining behavior. Within this raw bones framework of relatively independent actors related through norms, an endless constellation and combination or variety of actors and normative outputs and processes can be thought of. This is the kind of out-of-the-box thinking or framework that we will need to address the stagnation of international law. ${ }^{70}$ The international legal order is far more malleable than conventionally understood.

The historical dimension deserves some elaboration. ${ }^{71}$ In the Middle Ages ${ }^{72}$, the main actors or members of the international legal order were not states (they did,

${ }^{67}$ Jeremy Bentham, Principals of International Law, 1789.

${ }^{68}$ Grewe, supra note 55, at 464.

${ }^{69}$ Grewe, supra note 55, at 575 .

${ }^{70}$ As Willke supra note 36 at 17 put it, "globalization is confronting the nation states not just with a set of problems which defy the limits of national territories but which also defy the limits of law as a mode of governance and regulation".

${ }^{71}$ We use Grewe's work, supra note 55, for purely descriptive purposes to illustrate the kind of actors, processes and output at play in the past, without taking position on the accuracy of his specific legal positions or sub-division into six epochs. When Grewe divides and describes the different epochs or transformations that have occurred in the international legal order, he uses three main criteria (Grewe, supra note 55, at 30-31): delimitation, membership and organization. First, the "delimitation" of the international legal community (its intellectual substance, its socio-cultural structure, and its geographical scope"), e.g. in the Spanish age (1494-1648), the community of occidental "Christendom", in the British age (1815-1919), a society of "civilized" nations, in the United Nations age (1945-1989), "a universal community of mankind without substance". Second, the "essential characteristics of the members" or actors of the international legal community. Third, the organization or "constitutional development" of the community ("how is the creation of law provided for, from which sources is the law seen to flow, and which organs are entrusted with its codification into positive legal rules", ibid. at 31). By merely asking these questions of delimitation, membership and organization Grewe answers the challenge of whether it is possible to imagine an international legal order with actors, processes and outputs that are different from traditional international law or traditional international organizations. The answer is yes, both historically and conceptually. 
obviously, not yet exist), but the spiritual and temporal regime of the two universal powers, the Holy Roman Emperor and the Pope. ${ }^{73}$ Both empire and papacy had some form of superimposing authority, not completely unlike today's international organizations or more informal transnational networks. Underneath, however, were other actors such as kings, princes and an even longer list of dukes and other nobles, all of which were "autonomous communities capable of engaging in legal relations with one another" ${ }^{\prime \prime 4}$ and tied up in complex feudal relationships. The variety of actors, including transnational ones, goes further: "In addition to the chivalry, the ministry, from the clergy to the orders of priesthood, formed a tightly knit cohesive supranational element. The same is true, albeit to a lesser degree, of the medieval urban world of dependent and independent cities". ${ }^{75}$ At their height, the urban Hanseatic leagues were, indeed, independent subjects of international law with the power to conclude treaties. ${ }^{76}$ It requires only a small stretch of the imagination to make the link between this complex international legal order of the Middle Ages and the above described society of networks and crossing of the lines between public and private authority, national and international law.

During the Spanish age (1494-1648), other actors emerge, including states. Grewe points out, however, that in this period "States as such did not regularly enter into treaty relations ... sovereigns entered into treaties in their personal capacity. In numerous treaties it was expressly provided that the treaty would terminate with the death of one sovereign". ${ }^{77}$ In addition, "States at this age were not yet as closed and impermeable as the developed modern States. This was reflected by the fact that not only did sovereigns [emperors or kings] appear as subjects of international treaty relations, but so did other internal public authorities [princes and cities of their realm], who entered into their own treaties with foreign powers, or who took part in the treaties entered into between sovereigns". ${ }^{78}$ Here, the analogy with today's disaggregated or administrative state described earlier is not far away.

In the subsequent French age (1648-1815), what catches attention is "the specific, semi-State, semi-private intermediate position that the [colonial Dutch and English] trading companies asserted". ${ }^{79}$ These companies were "joint-stock companies" based on private capital but also "chartered companies" operating on the basis of concessions and privileges granted to them by States including trade monopolies and sovereign rights. Grewe notes that "[i]t was a matter of controversy in international legal theory during the nineteenth century whether the great trading companies were 'subjects' of international law, whether they held a 'sovereignty' of their own, or whether they were merely 'organs' of their parent country". 80 The status of these $16^{\text {th }}-18^{\text {th }}$ century trading companies is, no doubt, somewhat reminiscent of $21^{\text {st }}$ century transnational corporations and the many public-private partnerships developing today.

The international legal order has developed alongside changing forms of social organizations, from the Greek city-states and the jus gentium of the Romans to the

\footnotetext{
72 Grewe, supra note 55, identifies six epochs: (i) the Middle ages (fifth to fifteenth century), (ii) the Spanish age (1494-1648), (iii) the French age (1648-1815), (iv) the British age (18151919), (v) the League of Nations (1919-1944), (vi) the United Nations (1945-1989).

${ }^{73}$ Grewe, supra note 55, at 11.

${ }^{74}$ Grewe, supra note 55 at 12.

${ }^{75}$ Grewe, supra note 55, at 58.

${ }^{76}$ See Grewe, supra note 55, at 89.

${ }^{77}$ Grewe, supra note 55, at 196.

78 Ibid.

${ }^{79}$ Grewe, supra note 55, at 298.

${ }^{80}$ Grewe, supra note 55, at 302.
} 
empire of medieval Christendom and the modern territorial state.$^{81}$ Why should and could it not adapt to a new knowledge society of networks?

\section{Keeping the NeW aND the Old Accountable}

Should we be worried about the legitimacy or democratic accountability of these new types of cooperation? A number of conventional views must be challenged.

\section{a. All cooperation that affects freedom - binding or not - must be justified}

Firstly, it is not because something is not legally binding under international law that it does not affect public policy-making or individual freedom. Soft law or informal modes of cooperation with new actors and/or pursuant to novel processes may be as constraining - if not more so - than traditional treaties. ${ }^{82}$ Especially at the international level where centralized enforcement is absent, actors comply for reasons other than or beyond legal constraint (e.g. reputation, reciprocity, retaliation, prior consent to or perceived legitimacy of the norm in the first place ${ }^{83}$ ). These reasons may be activated as much for binding, traditional international law as they can be triggered by new forms of cooperation. ${ }^{84}$ Hence, for the Case Act in the United States to only require notification to the US Congress of agreements concluded by the United States that are "legally binding" does not make sense. ${ }^{85}$ Assuming that the objective of the Case Act is to keep the US Congress informed about international cooperation that matters, i.e., that may constrain the United States or impact US agencies or citizens, there are legally binding international agreements that have remained dead letter $^{86}$, as much as there are non-binding agreements or standards that have impacted US citizens directly (think of the Basel accords or ISO standards). In other words, the US Congress - and other parliaments for that matter ${ }^{87}$ - ought to be informed and be given a minimum of oversight (albeit

\footnotetext{
${ }^{81}$ See, for example, Sir Paul Vinogradoff, Historical Types of International Law, Bibliotheca Visseriana, 1923, quoted in Grewe, supra note 55, at 1.

${ }^{82}$ In respect of ICH standards, see Berman, Chapter 10, TOAEP book (" The ICH guidelines are considered voluntary, but they have all been implemented in the three $\mathrm{ICH}$ regions. Members will typically adopt the ICH guidelines as domestic (legally non-binding) guidance documents or guidelines").

${ }^{83}$ See R. Howse and R. Teitel, Beyond Compliance: Rethinking Why International Law Really Matters 1 Global Policy (2010) 127-136 and Thomas Franck, Legitimacy in the International System 82 Am. J. Int'l L. (1988) 705 at 706 ("in a community organized around rules, compliance is secured - to whatever degree it is - at least in part by perception of a rule as legitimate by those to whom it is addressed. Their perception of legitimacy will vary in degree from rule to rule and time to time").

${ }^{84}$ See Chris Brummer, Andrew T. Guzman \& Timothy Meyer, International Order Without Law: The Power of Soft Law in Global Governance, 2011.

${ }^{85}$ Similarly, in the US, Circular 175 and its coordinating role for the US State Department and obligation of publication and transmittal to Congress, 'does not apply to documents that are not binding under international law'. See U.S. State Department website, Circular 175 Procedure, at http://www.state.gov/s///treaty/c175/. Hence, if a document is not legally binding (ie, not an international agreement under the specific criteria of Circular 175), the obligations in Circular 175 do not apply.

${ }^{86}$ See as early as Oscar Schachter, Towards a Theory of International Obligation, 8 VA. J. INT'L L. 300 (1968), at 311 ("some 'laws,' though enacted properly, have so low a degree of probable compliance that they are treated as 'dead letters' and ... some treaties, while properly concluded, are considered 'scraps of paper'").

${ }^{87}$ In the UK, for example, the formalities which surround treaty-making do not apply to socalled Memoranda of Understanding (MOUs) - which the UK defines as international commitments that are not legally binding. As a result, MOUs are not usually published in the UK. See Treaties and MOUs, Guidance on Practice and Procedures, 2004, Treaty Section, Foreign \& Commonwealth Office, p. 1. Note, however, that the UN Treaty Handbook (p. 61) does consider MOUs as legally binding: 'The term memorandum of understanding (MOU) is
} 
indirectly through administrative agencies) in respect of all international cooperation that affects public policy-making and individual freedom. ${ }^{88}$ Whether an instrument is "legally binding" under international law is simply no longer the right criterion or proxy. To the extent new forms of cooperation matter or have an impact, they must be justified (where they fail or have no impact, we can learn from their mistakes; yet, justification or legitimacy is then of little or no concern). ${ }^{89}$

\section{b. Cooperation outside state consent can be legitimate}

Secondly, as traditional international law is based on state consent, we might presume (at least in the context of democracies, more on this below) that it is legitimate and democratically accountable on the view that state representatives speak for, and are controlled by, the people. Yet, legitimacy can come from other sources too, in particular, expertise, an inclusive and open process of deliberation or the implementation of effective outcomes. ${ }^{90}$ Experts and private bodies can create legitimate norms. ${ }^{91}$ In the United States, for example, for reasons of cost, expertise and effectiveness, it is a long-standing policy that standard-setting be done in private bodies, not government agencies. ${ }^{92}$ At the same time, the participation of federal agencies in standard-setting activities outside the government is encouraged. Most rule-addressees would probably rather have experts and a variety of stakeholders set safety or banking standards in a deliberative process, tested and updated based on the latest empirical evidence and checked only at arms length by politics (e.g. for due process, conflicts of interest and general guidelines), than national politicians. ${ }^{93}$ Traditional international law, based as it is on state consent, does not have a

often used to denote a less formal international instrument than a typical treaty or international agreement ... The United Nations considers MOUs to be binding and registers them if submitted by a party or if the United Nations is a party.'

${ }^{88}$ Joost Pauwelyn and George Pavlakos, Principled Monism and The Normative

Conception of Coercion under International Law, in Beyond the Established Orders: Policy Interconnections Between the EU and the Rest of the World (eds. Malcolm Evans \& Panos Koutrakos, 2011). See also Flückiger, Chapter 19, OUP book ("the validity of restrictions [imposed through informal or soft law] to these fundamental rights [of individuals] must be judged based on the same criteria as those applied to legal [hard law] restrictions, which means that they are subject to the requirements of legal basis, public interest and proportionality").

${ }^{89}$ Note, indeed, that certain IOs already require that even non-binding recommendations be submitted to domestic parliaments for adoption. See Art. 19:6 ILO Constitution; Art. IV:B(4) UNESCO Constitution; Art. XI FAO ; Ch. XIV, Art. 62 WHO.

${ }_{90}$ M. Barnet and M. Finnemore, Rules for the World: International Organizations in Global Politics (Cornell University Press, Ithaca, London 2004) 24. In European affairs, scholars have widely adopted the conceptual distinction between input- and output-related dimensions of democratic legitimacy, as developed by Fritz W. Sharpf in his book Governing in Europe: Effective and Democratic? Oxford, Oxford University Press, 1999, chapter 1.

${ }_{91}$ Case studies bear out that effectiveness and legitimacy are enhanced further by strengthening the interaction between multilateral and private forms of governance in ways that complement and reinforce each other: see, e.g., Axel Marx, Emilie Bécault and Jan Wouters, 'Private standards in forestry: assessing the legitimacy and effectiveness of the Forest Stewardship Council', in Axel Marx, Johan Swinnen, Miet Maertens and Jan Wouters (eds.), Private Standards and Global Governance. Economic, Legal and Political Perspectives, Edward Elgar Publishing, 2012, 60, at 91.

${ }_{92}$ See OMB Circular A-119 Federal Participation in the Development and Use of Voluntary Consensus Standards and in Conformity Assessment Activities, available at http://standards.gov/a119.cfm (directing agencies to use 'voluntary consensus standards' in lieu of 'government-unique standards' with a view to reduce to a minimum the reliance by agencies on government-unique standards, referring to justifications of cost to the government and reliance upon the private sector to supply government and national needs).

${ }^{93}$ See Jaffe supra note 122 at 363 ("Where not only technical skill but continuous judgment is demanded the legislature is helpless"); Willke supra note 36 at 7. 
monopoly on legitimate cooperation. New types of cooperation require new types of accountability, and special attention. ${ }^{94}$ Yet, conceptually, there is no reason why only traditional international law could qualify as legitimate or democratically accountable. ${ }^{95}$

\section{c. State consent is not (longer) a sufficient condition for legitimate cooperation}

Thirdly, the idea (referred to earlier) that traditional international law is necessarily legitimate and democratically accountable, because it is based on state consent, can no longer be accepted blindly (if ever it could). ${ }^{96}$ At the international level, the formal legitimacy that comes with a treaty or being part of international law is extremely thin. For treaties, all that is required is an agreement consented to by states. ${ }^{97}$ International law is agnostic on how this agreement was reached (process), who participated in its establishment (actors), what form it takes (instrument) and what is actually agreed on (substance ${ }^{98}$ ). The stop-clause of state consent - hereafter referred to as "thin state consent" - is all that is required to justify international law. A norm is part of international law not because it is right or reasonable but because states agreed to it (auctoritas, non veritas facit legem ${ }^{99}$ ). An agreement between two unelected heads of state recorded in informal but mutually accepted minutes, concluded after a five minute discussion in some secret, smoke-filled backroom is as much a "treaty" binding under international law as a formal convention between two states concluded after five years of multi-stakeholder dialogues under the auspices of the UN that was formally ratified by the democratically elected parliaments of both State parties.

\section{d. Do new forms of cooperation circumvent international law formalities?}

In the context of these thin validation requirements of traditional international law, the charge that new forms of cooperation circumvent the formal strictures of international law or are "devoid of the guarantees that come with law" ${ }^{100}$ rings rather hollow. What

\footnotetext{
${ }^{94}$ See Schepel supra note 46 at $413-4$ ("As long as we keep our constitutional aspirations and our legal imagination locked in the unity of law and state, we will not only fail to understand the phenomenon of global law conceptually but also fail normatively to grasp the opportunities to enhance its legitimacy"); Gunther Teubner, Breaking Frames: The Global Interplay of Legal and Social Systems (1997) 45 Am J Comp L 149, at 159 ("we are provoked to look for new forms of democratic legitimation of private government that would bring economic, technical and professional action under public scrutiny and control. That seems to me is the liberating move"); Willke supra note 36 at 7 ("An exceedingly complex society ... cannot be governed by a single monolithic unit, that is, politics or state, but instead depends on a multitude of capacities for self-governance and 'centers of expertise'").

${ }_{95}$ As Richard Mulgan explains, "'Accountability', the obligation to be called 'to account', is a method of keeping the public informed and powerful in check. It implies a world which is at once complex, where experts are needed to perform specialized tasks, but still fundamentally democratic in aspiration, in that members of the public assert their right to question the experts and exercise ultimate control over them" (Richard Mulgan, Holding Power to Account, Accountability in Modern Democracies, Palgrave, 2003, at 1).

${ }^{96}$ See Steven Wheatley, The Democratic Legitimacy of International Law, Hart Publishing, 2010; S. Besson, Theorizing the Sources of International Law, in S. Besson and J. Tasioulas (eds.), The Philosophy of International Law, OUP, Oxford, 2010, 163 at 166 and 175 (consent is insufficient to ensure the authority and legitimacy of international legal rules).

${ }^{97}$ See Klabbers, Chapter 10, OUP book (" in international law, considerations of pure form are hardly deemed relevant: there are no formal requirements attached to the making of international law, as long as there is substantive agreement between relevant parties").

${ }_{98}$ With the possible exception of rules of jus cogens which, in theory, invalidate any conflicting treaty.

${ }_{99}$ Hobbes, Leviathan, Vol. 2, ch. 26 ("authority not truth makes law").

${ }^{100}$ Klabbers, supra note 35 at 79.
} 
are these guarantees that come with international law? What are the strictures of formal international lawmaking that these new forms of cooperation circumvent? Other than state consent, there are none. In contrast to this thin consent, the emerging code of good practice for the development of standards or new forms of cooperation outside international law is normatively thicker. ${ }^{101}$ In many (though not all), the process is more inclusive, transparent and predictable. The actors involved are more diverse and expert. The output, finally, is elaborated more carefully and coherently, supported by a broader consensus (both ex ante when the norm is developed, and ex post when the norm is accepted because it works) and continuously questioned and adapted to practical, real world developments and needs $^{102}$ (the so-called "rough consensus and running code" ${ }^{103}$, without veto or opting-out power for any given actor, contrary to traditional international law ${ }^{104}$ ). Whereas traditional international law is driven by thin (state) consent, new forms of cooperation are increasingly based on thick (stakeholder) consensus. ${ }^{105}$

\section{e. Do new forms of cooperation circumvent domestic law formalities?}

The circumvention of domestic formalities linked to lawmaking must be taken more seriously. Domestic accountability mechanisms are at the core of keeping new models of international cooperation in check. ${ }^{106}$ In most countries, for a treaty to become binding it must receive the consent by Parliament or Congress. Certain new forms of cooperation may avoid this legitimizing step. ${ }^{107}$ For example, few, if any, national parliaments have explicitly consented to the Wassenaar Arrangement,

101 See ISEAL Code of Good Practice for Setting Standards Available at
http://www.isealalliance.org/code.
${ }_{102}$ See, in the field of intellectual property, G Dinwoodie, The International Intellectual Property Law System: New Actors, New Institutions, New Sources (2006) 10 Marquette Intellectual Property Law Review 205, at 211 (urging to "resist the effort to feed these developments [in non-traditional processes and fora] back toward the multilateral treaty system, because it is inevitable that the non-treaty based system will effect internationalization more efficiently than the further development of TRIPs").

${ }^{103}$ G. P. Callies and P. Zumbansen, Rough Consensus and Running Code: A Theory of Transnational Private Law, Hart Publishing 2010.

${ }^{104}$ See text below at note 165 .

105 Schepel, Chapter 16, OUP book, clarifies the notion of "consensus" in the standards world as follows: "Consensus' is best understood as shorthand for the near universal procedural core of private standard setting: elaboration of a draft by consensus in a technical committee with a composition representing a balance of interests, a round of public notice-and-comment of that draft with the obligation on the committee to take received comments into account, a ratification vote with a requirement of consensus, not just a majority, among the constituent members of the standards body, and an obligation to review standards periodically. The codes, manuals and 'standards for standards' where these rules are laid out are impressive tomes of private administrative law". See, for example, American National Standards Institute, ANSI Essential Requirements: Due process requirements for American National Standards (2010); CEN/CENELEC Internal regulations Part 2: Common Rules for Standardization Work (2012); DIN 820 (2009); British Standards Institute, BS 0:2011, A standard for standards: principles of standardization (2011).

106 See Verdier, Chapter 21, OUP book, based on a case study of Basel II and its implementation in the United States, concluding that "domestic law and politics substantially constrain the autonomy of national regulators engaged in [informal international lawmaking]". In support: Cassini, Chapter 18, OUP book and Berman, Chapter 22, OUP book.

${ }^{107}$ French practice, for example, distinguishes between "accords en forme solennelle" (Article 52 of the Constitution), concluded by the French President and subject to "ratification", and "accords en forme simplifié", concluded at the level of the government by the Minister of Foreign Affairs and subject to "approbation" (Circulaire du 30 mai 1997 relative à l'élaboration et à la conclusion des accords internationaux). See C. Chayet, Les accords en forme simplifiée (1957) 3 AFDI 205-26, J. Salmon, Les accords non formalizes ou 'solo consensu' (1999) AFDI 1-28. 
although for EU states its substance was implemented in an EU Regulation (controlled, once again, by governments, not parliaments). In Latin America, a debate is raging as to whether stand-by arrangements concluded between the IMF and countries seeking financial assistance from the IMF -- generally regarded as not being international agreements -- should nonetheless satisfy the legal domestic approval requirements for the conclusion of a treaty. ${ }^{108}$ The conditionalities set out in such IMF arrangements can have enormous consequences. Yet, in most cases, they have been adopted without parliamentary approval. In Canada, Basel II was implemented through guidelines rather than a regulation, partly to avoid the procedural requirements associated with adopting regulations. ${ }^{109}$ In the United States some have criticized as unconstitutional the trend of concluding so-called 'congressional-executive agreements' (adopted by simple majority in both houses of the US Congress) rather than treaties which, under Article II:2 of the US Constitution, require the advice and consent of two-thirds of the US Senate. ${ }^{110}$

Of course, the domestic approval of treaties is often a mere rubber-stamping of a fait accompli anyhow. ${ }^{111}$ Yet, to secure domestic democratic legitimacy ${ }^{112}$, a minimum degree of parliamentary or congressional oversight (not necessarily formal consent) of all international cooperation that affects public policy-making or individual freedom - treaty or not - must be available. To the extent lawmaking powers are delegated to administrative agencies, transparency, reason-giving and notice and comment procedures should apply to both the domestic and international activities and normmaking of these agencies, whether norms are binding under international law or not. A general guideline along these lines is already in place in Canada. ${ }^{113}$ Requirements under domestic administrative law of one (important) member may then de facto also apply to the operation of the entire international network. When it comes to private

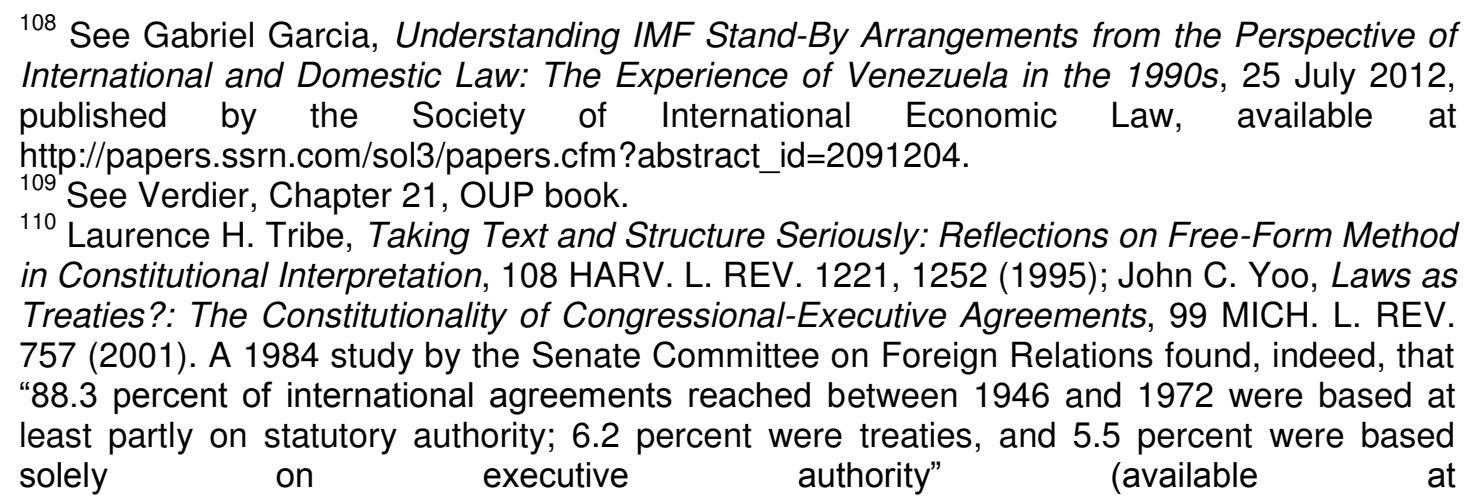
http://www.senate.gov/artandhistory/history/common/briefing/Treaties.htm). Yet, as Oona Hathaway has argued, a strong case can be made that congressional-executive agreements "enjoy increased legitimacy and stronger democratic credentials" as compared to "treaties" (Oona Hathaway, Treaties' End: The Past, Present, and Future of International Lawmaking in the United States 117 Yale Law Journal (2008) 1237 at 1307). Firstly, "treaties" are adopted without any involvement of the US House of Representatives. Secondly, a 2/3 super-majority is less democratic than a simply majority.

111 See David Y. Livshiz, Updating American Administrative Law: WTO, International Standards, Domestic Implementation and Public Participation, 24 Wisconson International Law Journal Law 961 (2007); Mulgan supra note 95 at 12 ("In modern representative democracies, little direct power remains to the people who must rely almost entirely on professional politicians and bureaucrats. Specialist institutions of accountability thus become increasingly important as means by which the public can try to keep governments in line").

${ }_{112}$ For an analytical framework to assess the democratic legitimacy of private standardsetting, see Nicolas Hachez and Jan Wouters, 'A Glimpse at the Democratic Legitimacy of Private Standards. Assessing the Public Accountability of GlobalG.A.P.', 14 Journal of International Economic Law 2011, 677, at 679-695, with a subsequent application to GLOBALG.A.P. (at 695-709).

${ }_{113}$ Berman, Chapter 22, OUP book. 
standards or norms, competition law may play a controlling role. ${ }^{114}$ Finally, judicial review must be available before domestic courts to protect fundamental rights of individuals and to ensure checks and balances between the legislature, executive and administrative agencies. Examples of such court control can be found in the $\mathrm{EU}^{115}$, The Netherlands ${ }^{116}$, United States ${ }^{117}$, Canada ${ }^{118}$ and Brazil. ${ }^{119}$ Also international courts and tribunals can play a controlling role (more on this below). ${ }^{120} \mathrm{It}$

114 See H. Schepel, 'Delegation of Regulatory Powers to Private Parties under EC Competition Law: Towards a Procedural Public Interest Test', (2002) 39 Common Market Law Review 31. In the United States, so-called Parker immunity (Parker v Brown, 317 US 341 (1943)) protects government action from antitrust scrutiny on the theory that the political process should be left alone to determine 'the public interest.'

${ }^{115}$ In the EU context only very few agencies have been allotted formal and binding decisionmaking powers. Such powers are, in accordance with the Meroni doctrine, strictly circumscribed executive powers, mainly relating to the registration of trademarks and certain chemicals, and the issuance of certificates (Cases 9/56 and 10/56 Meroni v. High Authority [1957-1958] ECR 133). See recently S Griller and A Orator, 'Everything under control? The "way forward" for European agencies in the footsteps of the Meroni doctrine' (2010) European Law Review, 3. For other examples of judicial review, see France v Commission (Case C-327/91 [1994] ECR I-3641), where the European Court of Justice declared void an act of the Commission whereby the Commission had sought to conclude a cooperation agreement with US anti-trust authorities. The Court was of the view that this agreement would bind the EU under international law but found that the Commission did not have the power to conclude such agreement. In Case C-233/02 France v Commission [2004] ECR I2759, France challenged guidelines on technical barriers to trade negotiated between the Commission and the US Trade Representative and US Department of Commerce, within the framework of the Transatlantic Economic Partnership. France argued that the guidelines formed a legally binding treaty, which in the constitutional framework of the EU should have been concluded by the Council. The Court disagreed: since the parties had agreed to apply the guidelines 'on a voluntary basis', the Court concluded that no legally binding agreement had been intended and, hence, none had been concluded.

${ }^{116}$ See Besselink, Chapter 3, TOAEP book (referring to cases of legislative referral to an informally set norm or standard where the question arose whether this standard itself acquires a legislative character and, if so, whether it must live up to constitutional requirements for legislative acts, in particular as regards its publication and public availability; see, e.g., Gerechtshof [Court of Appeal] of The Hague, 16 November 2010, LJN: BO4175; Raad van State, 2 February 2011, LJN: BP2750).

117 See, for example, Free Enterprise Fund v. Public Company Accounting Oversight Bd. 561 U. S. 1 (2010) (where the US Supreme Court struck down a provision requiring "good cause" before the US SEC could fire PCAOB board members, arguing that this would undermine executive control by the US President over the PCAOB). The PCAOB is heavily involved in international standard-setting through bilateral agreements with foreign authorities as well as membership in international networks such as the International Forum of Independent Audit Regulators. See http://pcaobus.org/International/Pages/default.aspx.

118 See, for example, A. v Ontario Securities Commission ([2006] CanLII 14414 (OSC)) where the Ontario Superior Court of Justice evaluated the constitutional legitimacy of the investigations carried out by the Ontario Securities Commission in execution of a MoU between this Canadian authority and the US SEC.

${ }_{119}$ See, for example, Superior Court of Justice (Superior Tribunal de Justiça - STJ) (Preliminary Injunction (Medida Cautelar) n. 17.350-RJ, October 7, 2010, upholding a lower court finding that the implementation in Brazil of certain IOSCO guidelines on the remuneration of administrators violated the legality principle, discussed in Nasser and Machado, Chapter 4, TOAEP book.

120 See Klabbers, Chapter 10, OUP book (" [international] courts by and large tend to approach IN-LAW [informal international lawmaking] as they would approach regular law: while the drafters of IN-LAW typically will want to escape both democratic and judicial accountability, courts are not too keen on letting them do so"). In this respect, Scott and Sturm have advocated a role for courts (including international tribunals) beyond rule enforcement or formal adjudication, namely: courts as "catalysts" which "facilitate the realization of process values and principals that are crucial to new governance's legitimacy and efficacy by the institutional actors responsible for norm elaboration within new 
is not that traditional international law is legitimate and new forms of cooperation are not, or vice versa. Both require close scrutiny and vigilance. ${ }^{121}$ Both can be more, or less, democratically legitimate depending on the circumstances. ${ }^{122}$

\section{f. A calibrated approach to accountability}

A one-size fit all model of accountability ${ }^{123}$ such as Parliamentary approval no longer works. ${ }^{124}$ As Krisch remarks, "[w]e have arrived at a point where political and functional needs bar a return to the old order of international law in which difference was processed through consent-based law-making and strictly domestic mechanisms of implementation". ${ }^{25}$ Depending on the subject matter (e.g. fighting inflation or setting food standards versus trade policy or peace and security) and impact of the norms (e.g. purely local or global), an appropriate division of labour must be worked out between experts, politicians and courts, the international, regional and national level, public officials and the private sector, congress, the executive and administrative agencies, formal and informal law. In each case, an appropriate balance must be found between effectiveness (and the independence of action this might require) and accountability (and the control or oversight that comes with it). Crucially, independence of action (e.g. decision-making by experts) must not mean "agencies on the loose". Independence in day-to-day activity (e.g. little, if any,

governance" (J. Scott and S. Sturm, Courts as Catalysts: Rethinking the Judicial Role in New Governance, 13 Columbia Journal Of European Law 565 (2007) at 567; in the specific context of the WTO, see Joanne Scott, International Trade and Environmental Governance: Relating Rules (and Standards) in the EU and the WTO 15 European Journal of International Law (2004) 307-354).

${ }_{121}$ See Jurgen Habermas, Between Facts and Norms-Contributions to a Discourse Theory of Law and Democracy, Polity Press, Cambridge, 1995 at 441-2 ("the only thing that serves as a 'palladium of liberty' against the growth of independent, illegitimate power is a suspicious, mobile, alert, and informed public sphere that affects the parliamentary complex and secures the sources from which legitimate law can arise", emphasis in original).

${ }_{122}$ LL Jaffe, 'An Essay on Delegation of Legislative Power l' (1947) 47 Columbia Law Review 359 , at 360 ("We must not take lightly the objection to indiscriminate and ill-defined delegation. It expresses a fundamental democratic concern. But neither should we insist that 'law-making' as such is the exclusive province of the legislature. The aim of government is to gain acceptance for objectives demonstrated as desirable and to realize them as fully as possible. We should recognize that legislation and administration are complementary rather than opposed processes; and that delegation is the formal term and method for their interplay").

${ }^{123}$ For purposes of the IN-LAW project, we have distinguished between (i) " accountability mechanisms strictly defined ", that is, ex post and institutionalized mechanisms holding an actor to account for its activities (e.g. electoral, hierarchical, supervisory, fiscal, and legal), (ii) "preconditions" required to enable such accountability mechanisms to work (such as transparency, the setting of a clear mandate or benchmark against which an actor can be held accountable), and (iii) "other accountability promoting measures" (ensuring the responsiveness of actors, such as ex ante appointments, peer pressure or market-based sanctions), see Pauwelyn, Chapter 1, OUP book.

${ }_{124}$ See Corthaut et al, Chapter 14, OUP book and also Amtenbrink, Chapter 15, OUP book. See J. Cohen and C. Sabel, 'Global Democracy?', (2005) 37 NYU Journal of International Law and Politics 763, 765 (Principal-agent models that deeply shape our ideas about legitimate and effective delegation of authority are 'irrelevant' in global administrative space.). See also J. Black, 'Constructing and contesting legitimacy and accountability in polycentric regulatory regimes', (2008) 2 Regulation \& Governance 137.

${ }^{125}$ Nico Krisch, Beyond Constitutionalism, The Pluralist Structure of Postnational Law (OUP, 2010) 188 and 271 ('relativize the place of electoral mechanisms in democratic theory and shifts our

focus to the elements of popular control possible without elections - or with the very limited input from

elections at a national (sometimes also regional) level'). 
ongoing control by politicians over, for example, interest rate setting by central banks or scientific decisions taken by food safety agencies) can, and must, be compensated by ex ante controls (such as setting a clear mandate or benchmark against which actors can be held accountable; guidelines; appointments; or rules on conflicts of interest) and ex post controls (such as re-adjustment of guidelines, financial accountability or complaints mechanisms). A requirement that each and every government regulation or guideline be approved by Congress ${ }^{126}$ would err on the side of accountability (in the EU context referred to as accountability "overload"127; in an ICANN study labeled "multiple accountabilities disorder (MAD)"128) and make effective, high quality norm-setting practically impossible. Conversely, regulating through purely informal guidelines or expert reports developed without publicity, reason-giving or public interest oversight would err on the side of effectiveness and undermine the fundamental idea of rule by the people. Moreover, the first extreme (accountability overload) would, in the longer term, also turn unaccountable, as regulators would find under-ground ways to avoid scrutiny (formalization of rule-making, in a type of cat and mouse game, always creates the next level of informal rule-making). Similarly, the second extreme (no oversight) would, in the longer term, also turn ineffective as neutrality, quality and trust in the norms created is likely to wane and with it their legitimacy and effectiveness. Although a balance must be found between the two, ultimately, effectiveness and accountability go hand in hand.

\section{g. New forms of cooperation as first-best, normatively superior solution?}

In the end of the day, what does it add to conclude a legally binding treaty, rather than a scheme or accord outside international law? Not legitimacy, nor effectiveness (at least not per se). Legitimacy depends on many factors beyond being or not being part of international law (such as process, inclusion of all stakeholders or domestic input and ratification). In some countries a formal treaty may trigger effective domestic oversight mechanisms. In many other countries, however, treaties automatically enter the domestic legal system without much internal scrutiny and are, at times, even superior to domestic law, thereby raising questions of legitimacy rather than alleviating them. To the extent treaties require a one-size fit-all hard law implementation, they disable the domestic flexibility that comes with many new types of cooperation. This can make treaties less (rather than more) accountable as compared to other international norms that can be adjusted to domestic needs and sensitivities through domestic implementation and scrutiny. Moreover, the rigidity of treaties once adopted (amendment normally requires unanimity and a new, formal round of Parliamentary approvals) makes them less (rather than more) democratic.

\footnotetext{
${ }^{126}$ To this effect, see the Regulations from the Executive in Need of Scrutiny (REINS) Act (H.R. 10) which passed the US House Judiciary Committee in October 2011 (requiring the US Congress to take an up-or-down vote on all government regulations that will have an economic impact of at least 100 million US\$ or major increases in costs or prices for consumers) and the Regulatory Accountability Act (RAA) (H.R. 3010, also submitted to the 112th Congress) which would impose all requirements in the Administrative Procedure Act (APA) and more on all agency rule-making (formal and informal) that impact the economy significantly and heighten judicial scrutiny of such rules. For a strenuous critique by a group of US administrative law professors see http://www.law.upenn.edu/blogs/regblog/Letter\%20to\%20House\%20Judiciary\%20Committee \%200n\%20HR\%203010.pdf and by Public Citizen see www.citizen.org/documents/REINSAct-Fact-Sheet-20110204.pdf ("a deeply flawed bill that would handicap the federal agencies and add a considerable workload to a legislative body which already struggles with time constraints").

${ }^{127}$ See Vos, Chapter 17, OUP book.

${ }^{128}$ See J Koppell, 'Pathologies of Accountability: ICANN and the Challenge of "Multiple Accountabilities Disorder"' (2005) 65 Public Administration Review 94, 98-99.
} 
As Krisch points out, "[r]evisability is commonly seen as a key element of democratic orders ... Ensuring the revisability of norms and decisions then becomes a key democratic demand and pluralism's legal and institutional openness facilitates it". ${ }^{129}$

Effectiveness, in the absence of centralized coercion or enforcement, does not

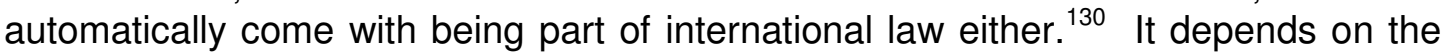
specific monitoring or enforcement scheme in place, which could be weak under international law, as is for example the case for UNESCO or ILO commitments, and could be strong outside international law, e.g. the OECD's Financial Action Task Force or the FAO Code of Conduct for Responsible Fisheries, both backed-up with effective sanctions. ${ }^{131}$

No inherent or automatic benefits come with being part of international law. ${ }^{132}$ Yet, to conclude a treaty, in particular a multilateral one within a formal 10 , requires huge transaction costs and once concluded is hard to adapt to changing circumstances. Whatever the legitimacy that comes with traditional international law (at the international level, relatively little) can be compensated both internationally (thick consensus instead of thin consent) and at home (parliamentary/congressional oversight; administrative notice and comment procedures; judicial review; other checks and balances). Indeed, in the end, new forms of cooperation can be more (rather than less) accountable or responsive to a broader audience and better (rather than worse) adapted to the needs of modern society. To that extent, traditional international law is no longer the first-best option to which soft or informal law can only aspire.

\section{Power and Externalities or How to Take Account of All Affected Parties}

\section{a. $\quad$ Power remains asymmetric but is increasingly dispersed}

Do new, often informal modes of cooperation enhance the risk that powerful actors take control or game the system to their advantage $?^{133}$ Does traditional international law not better protect the weak, by imposing equal rules for all (right rather than might)? There is no denying that in a diverse and complex network/knowledge

\footnotetext{
${ }^{129}$ Krisch, supra note 125 , at 273.

130 See Franck supra note 83 at 711 ("In place of coercion, there is only the claim to compliance, based on social entitlement, which a legitimate rule makes on, and on behalf of, all members of the community ... The legitimacy of a rule, or of a rule-making or rule-applying institution, is a function of the perception of those in the community concerned that the rule, or the institution, has come into being endowed with legitimacy: that is, in accordance with right process").

131 See Jürgen Friedrich, 'Legal Challenges of Non-binding Instruments: The Case of the FAO Code of Conduct for Responsible Fisheries' in A. von Bogdandy, R. Wolfrum, J. Von Bernsdorff, Ph. Dann and M. Goldmann (Eds.), The Excercise of Public Authority by International Institutions: Advancing International Institutional Law, Heidelberg: Springer, 2010 , at 511

${ }_{132}$ Yet, as noted earlier, we of course acknowledge that sometimes States continue to have an interest, and good reasons, to tie their counterparts into a binding bilateral or multilateral treaty scheme (think of disarmament treaties like the ABM Treaty during the Cold War, or multilateral environmental treaties like the Kyoto Protocol which do not tolerate reservations in order to preserve the integrity of the greenhouse emission reduction scheme).

${ }^{133}$ See Eyal Benvenisti, 'Coalitions of the Willing' and the Evolution of Informal International Law in Coalitions of the Willing - Avantgarde or Threat? 1 (C. Calliess, C. Nolte, G. Stoll, eds., 2008). See also Klabbers, Chapter 10, OUP book ("IN-LAW is effective for the powers that be, leaving disadvantaged groups little emancipatory possibilities").
} 
society, power continues to play a role. ${ }^{134}$ Staying on top of activity and information becomes increasingly difficult, especially for weak actors (e.g. small, resourcestarved least-developed countries or interest groups that are difficult to organize). The availability of a more diverse "normative menu" of options or forms in which states can cooperate, may also enhance strategic decisions in the choice between formal and informal cooperation, soft and hard law. ${ }^{135}$ However, forum shopping has always existed also amongst formal IOs or between traditional sources. ${ }^{136}$ New forms of cross-border cooperation will not neutralize power differences, although the emergence of new actors, both states and non-state entities, implies a more competitive environment where power is increasingly dispersed and mutually checked. ${ }^{137}$ Countries like China and Brazil contest and check US power - in fact, they do this increasingly together with their BRICS partners. ${ }^{138}$ Transnational NGO, business and consumer networks, in turn, exert pressure on state powers. Even within states, internationally active regulators, agencies or judges, enter power plays and thereby impose certain checks and balances. Willke refers to a shift from powerbased to knowledge-based decision-making, the emergence of lateral world systems and a concomitant "shift from a normative to a cognitive mode of decisionmaking". ${ }^{139}$ In addition, interactions between networks of cooperation, formal or informal, can provide further checks and balances, and thereby enhance both accountability and effectiveness. Krisch rightly describes "the interplay of different layers of law in a pluralist order as an accountability mechanism". ${ }^{140}$ Pluralism is not just about competition, but also about addressing complexity through individual ingenuity which combined offers solutions which no single actor could have constructed (the whole is mightier than the sum of its parts). ${ }^{141}$

And, obviously, also traditional international law is not devoid of power politics, notwithstanding the legal fiction of sovereign equality. ${ }^{142}$ Once more, it is less relevant whether the cooperation is legally binding or not, new or traditional. More relevant is whether it is bilateral or multilateral, symmetrical or asymmetrical, whether all affected stakeholders are involved or not, whether the process is inclusive,

\footnotetext{
${ }^{134}$ See, for example, Jonathan S. Davies, Challenging Governance Theory, From Networks to Hegemony, Policy Press, 2011 (at 152, rightly questioning that networks "transcend structures of power and domination").

${ }^{135}$ See Shaffer \& Pollack chapter in OUP book.

${ }^{136}$ Think of Palestina turning to UNESCO for membership (based on a majority vote) when facing vetoes for UN membership. In the IP field: G Dinwoodie and R. Dreyfuss, Designing a Global Intellectual Property System Responsive to Change: The WTO, WIPO and Beyond (2009) 46 Houston Law Review 1187 (the "move [from WTO] to WIPO is, however, intriguing, for it suggests an institutional design that could make the international intellectual property system more responsive to changing needs").

${ }^{137}$ As Willke supra note 36 at 30 puts it: "A general strategy for enhancing the resilience of democracy is to reinvigorate its original impulse of deconstructing monolithic power structures, thus distributing responsibilites for public affairs on many actors instead of a few, and dispersing responsibilities for societal decision-making in many arenas".

${ }_{138}$ One recent example is the non-support by the BRIC countries for an international code of conduct for outer space activities proposed by the EU, because they were insufficiently consulted in the EU's drafting of the draft code: see Micah Zenko, 'A Code of Conduct for Outer Space', Policy Innovation Memorandum No 10, European Council of Foreign Relations, November 2011.

${ }^{139}$ Willke supra note 36 at 15 (referring at 16 to "an instructive discourse between regulators and regulated instead of trying to enforce rigid norms in cases where norms lack the 'requisite variety' ... to cope with exceedingly complex problems").

${ }^{140}$ Krisch, supra note 125, at 272.

${ }^{141}$ See Shaffer and Pollack, OUP book, Chapter 11 ("shortcomings or biases of one ... mechanism may (although not necessarily) be mirrored or compensated for within other, overlapping or competing mechanisms").

${ }^{142}$ Michael Byers, Custom, Power and the Power of Rules, 1999.
} 
transparent and based on facts rather than secret and driven by strategic power plays. Both extremes happen in traditional international law and in new forms of cooperation.

\section{b. Keeping Cooperation Accountable Toward All Affected Parties}

Probably the core challenge for new forms of cooperation is their taking into account of external stakeholder interests. ${ }^{143}$ Coalitions of the willing may be created. Yet, these may also affect (directly or indirectly) outsider state or private actors (think of the $\mathrm{ICH}$, Basel or the FATF). Such coalitions may more efficiently address collective action problems or more accurately and efficiently tackle a problem (e.g. harmonized certification requirements for the approval of pharmaceuticals at the $\mathrm{ICH}$, involving only the USA, EU and Japan as the leading market players). Yet, the impact of these coalitions often extends, de jure or de facto, positively or negatively ${ }^{144}$, beyond their membership. In the case of the $\mathrm{ICH}$, for example, countries like Brazil or China are pressed to de facto adopt $\mathrm{ICH}$ standards although these standards have been written without their input. ${ }^{145}$ In the context of Basel financial standards, Claessens has argued that Basel II was shaped by banks and regulators from industrialized countries and is not responsive to the needs and circumstances of developing countries. ${ }^{146}$ The $\mathrm{ICH}$ has been criticized for including the pharmaceutical industry as an equal participant with regulators but excluding patient or consumer organizations. Basel has been blamed for being responsive to large banks, but not or less so to smaller financial institutions or users. The Forest Stewardship Council, which for 20 years provides a unique system of transnational private regulation for the preservation of forests, has been facing a North-South divide both in terms of formal representation/participation as well as in relation to certificate adoption. ${ }^{147}$ GLOBALG.A.P., the world's most extensive system of private food safety standards, faces a similar challenge of inclusion of consumers and small food producers. ${ }^{148}$

On the one hand, this type of transnational cooperation is a step forward as compared to, say, the US or a US agency unilaterally setting standards and imposing them on the rest of the world (in the $\mathrm{ICH}$, at least EU and Japanese interests are taken on board). ${ }^{149}$ On the other hand, the legitimacy of certain transnational cooperation still leaves to be desired as its accountability mechanisms are not commensurate with its real life impact. ICH guidance on good clinical practices (GCPs), for example, allows the pharmaceutical industry to run clinical trials in which the patients in the control group can be treated with placebos instead

\footnotetext{
${ }^{143}$ Karl-Heinz Ladeur, The Emergence Of Global Administrative Law And Transnational Regulation, IILJ-NYU Working Paper 2011/1 (2011) at 11 ("The problem ... is to be seen in the fact that the consideration of outsiders both within networks and outside is far from being guaranteed by the new logic of networks. In this respect, the role of state-based traditional law, constitutional in particular, cannot be completely superseded").

${ }^{144}$ Indeed, the fact that a club of rich, developed countries invests time and resources to establish state-of-the-art standards, without any support of other countries, could also be see as free-riding by these other countries on public goods produced by the countries member of the club.

${ }^{145}$ Regarding the ICH see Ayelet Berman, TOAEP book, Chapter 10. Regarding the FATF see Shawn Donnelly, TOAEP book, Chapter 5.

${ }^{146}$ Stijn Claessens et al, 'The Political Economy of Basel II: The Costs for Poor Countries' (2008) The World Economy 313.

147 See Axel Marx, Emilie Bécault and Jan Wouters, supra note 91, at 83-86.

${ }_{148}$ See Nicolas Hachez and Jan Wouters, supra note 112, at 708.

149 See Braithwaite, 'Prospects for Win-Win International Rapprochement of Regulation' in S Jacolds (ed), Regulatory Cooperation for an Interdependent World (Paris: OECD, PUMA, 1994 (suggesting that international regulatory processes may actually enhance democracy, where they are open to a wider variety of stakeholders than many domestic processes, and where they allow for more open contestation of policies).
} 
of the existing proven therapy. Often such clinical trials are conducted in developing countries, to lower costs. Using placebos there, instead of existing treatments, has led to patients dying who could have been saved by using existing proven therapy. ${ }^{150}$ Had developing countries been involved in the establishment of these GCPs such adverse consequences might have been avoided. ${ }^{151}$ Although the Kimberley Scheme on conflict diamonds involves both the diamond industry and NGOs, critics have pointed out that the interests of small, artisanal diamond miners (who may have a much harder time complying with Kimberley rules than big mining corporations such as De Beers) were not represented. ${ }^{152}$ Similar critiques have been raised in respect of internet standards, arguing that recent changes in the internet's architecture deviate from the internet's original design principles and benefit network providers at the expense of internet users, application developers and content providers. ${ }^{153}$ As Mulgan explains, "[a]ccountability forces members of the government into dialogue with their citizens ... A second justification for accountability involves the principle that those whose rights or interests are adversely affected by the actions of someone else have a right to hold that person to account". ${ }^{154}$

Increased participation of external stakeholders is, therefore, a hallmark of recent reforms be it at the Basel Committee ${ }^{155}$ or the $\mathrm{ICH}^{156}$ In June 2012, for example, the $\mathrm{ICH}$ adopted a major overhaul of its principles of governance (inter alia, to ensure "regulatory oversight as well as integrity of the entire process"), removing the veto power and equal participation rights of the pharmaceutical industry, increasing transparency through publication of technical documents and enhancing global outreach by involving new countries and regional harmonization initiatives. ${ }^{157}$ Examining Brazil in the context of a number of transnational cooperation schemes, Nasser and Machado conclude that "[w]here Brazil had until recently no voice in the outputs of the networks, it begins to be heard. Where it had already one, it is now more audible". ${ }^{158}$ Assessing the International Strategy for Disaster Reduction, Corredig concludes that "[i]f anything, the transparency of the decision-making process at the international level in the context of [disaster risk reduction] often appears to be superior to the transparency of the mechanisms successively adopted at the national level". ${ }^{159}$

\footnotetext{
${ }^{150} \mathrm{P}$. Lurie and SM Wolfe, 'Unethical Trials of Interventions to Reduce Perinatal Transmission of the Human Immunodeficiency Virus in Developing Countries ' (1997) 337 New England Journal of Medicine 853.

${ }^{151}$ See also Berman, Chapter 10, TOAEP book (" The WHO and other NGOs have raised the concern that the $[\mathrm{ICH}]$ standards are unnecessarily high (that is, not justified by safety, efficacy or quality concerns) for developing countries and small manufacturers, leading to a potential squeeze out of local production. There have similarly been claims that being too costly, the ICH standards on clinical trials are unattainable in developing countries, leading to a decrease in clinical trials in developing countries on pharmaceuticals that would benefit the local population").

${ }^{152}$ See Vidal, Chapter 15, TOAEP book.

${ }_{154}$ See Barbara van Schewick, Internet Architecture and Innovation, MIT Press, 2010.

${ }^{154}$ Mulgan supra note 95 at 13.

${ }^{155}$ See Michael S Barr and Geoffrey P Miller ('Global Administrative Law: The View from Basel' (2006) 17 European Journal of International Law 15) who describe how the Basel Committee engaged in a very substantial international notice-and-comment process throughout the development of Basel II, in response to concerns about the lack of adequate rule-making and participatory procedures at the international level.

${ }^{156}$ See Berman, Chapter 21, OUP book.

${ }^{157} \mathrm{ICH}$ Press Release, Fukuoka, Japan, June 2012, ICH Parties Agree on New Principles of Governance, available at http://www.ich.org/fileadmin/Public_Web_Site/News room/BPress_Releases/ICH_GCG_Press_Releases/Press_Release_Fukuoka_2012.pdf.

${ }^{158}$ Nasser and Machado, Chapter 4, TOAEP book.

${ }^{159}$ Corredig, Chapter 14, TOAEP book.
} 
Domestically, accountability mechanisms must be strengthened so as to legitimize norms towards, in particular, internal stakeholders. Think of congressional oversight, application of notice and comment procedures or judicial review discussed above. ${ }^{160}$ Internationally, accountability mechanisms must be set up to make sure that norms agreed to take account of all affected interests including external stakeholders: In the $\mathrm{ICH}$, for example, by involving consumer or patient organizations on top of pharmaceutical companies as well as by giving voice and input to affected states beyond the USA, EU and Japan; At the Basel Committee, by involving stakeholders other than large international banks and industry associations as well as emerging economies. Such international mechanisms may include complaints or ombudsmantype mechanisms such as the Inspection Panel set up at the World Bank. The use of domestic procedures (such as US notice and comments procedures which are generally open to foreigners) may also be a tool for external stakeholders to voice concerns. ${ }^{161}$ As Verdier points out, "accountability mechanisms at the international level should be designed to address gaps that are not addressed by the domestic process, rather than to duplicate it". ${ }^{162}$

\section{c. Creating the best of both worlds? Thick stakeholder consensus rather than thin state consent}

This way, the best of both worlds could emerge: norms that are domestically grounded and accepted, while at the same time avoid imposing externalities on outsiders. ${ }^{163}$ The informal nature and flexibility of new forms of cooperation (be it the $\mathrm{ICH}$ or the G-20) allows for this adaptation to take account of new interests much more so than, for example, in the UN or WTO where institutional reforms are excruciatingly difficult because of state consent. ${ }^{164}$ At that level as well, new forms of cooperation can offer the best of both worlds: normatively superior cooperation (thick consensus as opposed to thin consent, discussed earlier), while at the same time

\footnotetext{
${ }^{160}$ As Cassini, Chapter 18, OUP book puts it: "the more informal the network [at the international level], the greater the accountability and review demanded of the States and domestic legal orders". Yet, as Verdier puts it (Chapter 22, OUP book), "[t]o the extent that domestic accountability mechanisms often focus more on ex post process than on ex ante inputs, these processes may struggle to keep pace with contemporary forms of complex international standard-setting embodied by Basel II".

${ }^{161}$ In May 2011 the OECD issued a "Draft Recommendation on Regulatory Policy and Governance" which recommends that regulators should "[e]nsure that regulatory measures contemplated in all fields take into account any international frameworks for cooperation in the same field and are also designed to take into account their possible effects on parties outside the jurisdiction where they are to be applied. Consultation should include any external interests with the aim of avoiding unnecessary international frictions" (Section 12 of the OECD, 'Draft Recommendation on Regulatory Policy and Governance' (2011) http://www.oecd.org/dataoecd/49/43/48087250.pdf).

${ }^{162}$ Verdier, Chapter 21, OUP book.

${ }^{163}$ See Willke supra note 36 at 72 arguing that transnational law may be normatively superior to domestic law as it "carries the chance for greater heterogeneity and an influx of distributed intelligence provided by many actors, organizations and institutions"; Schepel supra note 46 at 408 ("It may well be thought that national representation is neither sufficient nor necessary for 'consensus', and that we will be able to substitute pure procedural legitimacy for such notions").

${ }^{164}$ Verdier, Chapter 21, OUP book, refers, in the context of Basel II, to "emerging forms of interactive international policy-making, where standards are implemented over several years and continually revised in light of new information and feedback from regulators, the industry, and markets".
} 
addressing (at least some of) the collective action problems that a system based on state consent cannot tackle. ${ }^{165}$

The reality is, indeed, that the requirement of state consent, prevailing in traditional international law, is both too lenient and too strict. Too lenient or easy, because the validation rules of international law, discussed earlier, do not care about transparency, inclusiveness or impartiality of the process or actors involved, nor about the effectiveness, coherence or substantive/constitutional quality of what is agreed on. Too strict or difficult, because concluding rules on, for example, climate change or the WTO's Doha round requires individual consent of each state involved. That thick consensus, as we know it in the standards world, can be procedurally and substantively superior was discussed above. At the same time, it can also address certain collective action problems. Where thin state "consent" implies a veto or optout power for each individual state, "consensus", as it is defined in the standards world, provides for a procedurally inclusive and fair process but at the end of the day takes away individual veto power. The ISO/IEC Guide 2, for example, defines "consensus" as follows:

[g]eneral agreement, characterized by the absence of sustained opposition to substantial issues by any important part of the concerned interests and by a process that involves seeking to take into account the views of all parties concerned and to reconcile any conflicting arguments.

In other words, the views of all parties concerned must be taken into account and an attempt must be made to reconcile conflicting arguments. Yet, once "general agreement" is reached, that is, there is no "sustained opposition" to "substantial" issues by an "important" part of the concerned interests, the norm or standard can be adopted to address the problem identified.

In sum, when looking for global public goods (be it progress on climate change or sustainable development) it may, therefore, be better to focus on these new forms of cooperation involving a variety of actors instead of striving toward state-centered supra-national authorities or IOs with collective and formally delegated powers that can constrain or coerce individual states. ${ }^{166}$ If carefully designed and kept in check, these new forms can be both domestically grounded and accepted (through internal accountability mechanisms such as administrative notice and comment procedures, congressional oversight and judicial review) and take account of transnational externalities (if the transnational network is sufficiently open to external stakeholders). They can be both procedurally inclusive and substantively coherent, and overcome collective action problems (thick consensus rather than thin

\footnotetext{
${ }^{165}$ As Cassini (Chapter 18, OUP book) remarks, "the informal character of global networks implies that each State retains a wide discretion in designing its own institutional mode". This, as Cassini points out, leads to a (happy) paradox: although global networks are "established in order to face global needs, the informality of such mechanisms allows States to retain their powers in a way that would not be possible if more formalised techniques of global governance were adopted".

${ }^{166}$ As Slaughter and Hale put it: "Even if we could replicate domestic institutions at the international level, they would likely prove inadequate for the complexities of global governance" (Anne-Marie Slaughter and Thomas Hale, A Covenant to Make Global Governance Work, 2005, at 2, available at www.openDemocracy.net).
} 
consent). ${ }^{167}$ This is a far cry away, even the anti-thesis of, conventional critiques against new types of international cooperation. ${ }^{168}$

Problem-solving in an increasingly diverse and complex network/knowledge society will require action beyond what states can shoulder. It needs pragmatic deliberation involving multiple sources of knowledge, experience and control; not uni-dimensional involvement of increasingly detached and under-resourced diplomats paralyzed by geopolitical power plays, hidden value systems or zero-sum distributional calculations. The absence of centralized lawmaking in international law has its problems and can make collective action more difficult. At the same time, the decentralized, heterarchical nature of the international system, where new processes, actors and forms of cooperation can emerge almost organically, also has advantages as compared to more monolithic, State-centered national legal systems. ${ }^{169}$ This decentralized activity and control with distributed problem solving and multiple actors and interactions at a diversity of levels can ultimately make the international legal system more (rather than less) adaptable to the challenges of the network/knowledge society described earlier.

\section{THE THRESHOLD OF TRADITIONAL INTERNATIONAL LAW VERSUS THE EMERGENCE OF PROCEDURAL META-NORMS FOR ANY RESTRICTION ON FREEDOM}

\section{a. The threshold for a norm to be part of traditional international law}

In the short to medium term, do any of the new or informal types of cooperation described above amount to international law, traditionally defined? ${ }^{170}$ As discussed earlier, traditional international law is anything but formalistic. Informal instruments (such as oral agreements or custom) can bind; non-binding instruments (such as ISO standards) can be very formal. For there to be a treaty in the sense of the Vienna Convention all that is required is an agreement consented to by states. ${ }^{171}$ Jan Klabbers, for example, has demonstrated that international courts and tribunals have commonly referred to and applied as part of international law press communiqués and informal agreements or guidelines. ${ }^{172}$ What matters is the intent of the parties

\footnotetext{
${ }^{167}$ As Flückiger put it (Chapter 19, OUP book), "taking [informal international lawmaking] seriously-and soft law more generally-offers a remarkable opportunity to reinvent democracy".

${ }_{168}$ See, for example, P. Alston, "The Myopia of the Handmaidens: International Lawyers and Globalization", in European Journal of International Law, 1997, vol. 8, 435 (writing that new cooperation forms imply "the marginalization of governments as such and their replacement by special interest groups" suggesting "a move away from arenas of relative transparency into the back rooms").

${ }_{169}$ See Joost Pauwelyn, Optimal Protection of International Law (CUP, 2008) 198 ('Most commentators regard the lack of centralized law-making and enforcement as the core weakness or original sin of the international legal system. In contrast, ... the starting point of no collective intervention may actually be one of international law's strongest selling points').

170 See Pauwelyn chapter and Ruiter \& Wessel chapter in OUP book; B. Kingsbury, The Concept of "Law" in Global Administrative Law, 20 EJIL (2009) 23.

171 See Article 2.1(a) of the Vienna Convention on the Law of Treaties: "'treaty' means an international agreement concluded between States in written form and governed by international law, whether embodied in a single instrument or in two or more related instruments and whatever its particular designation".

172 Klabbers, Chapter 10, OUP book. See, for example, the Case Concerning Maritime Delimitation and Territorial Questions between Qatar and Bahrain (Qatar v Bahrain) (Jurisdiction and Admissibility) [1994] ICJ Rep 112 at para. 25 (holding that the agreed minutes between Qatar and Bahrain 'enumerate the commitments to which the Parties have consented. They thus create rights and obligations in international law for the Parties. They constitute an international agreement') and Case Concerning Pulp Mills on the River Uruguay (Argentina v Uruguay) (Judgment) [20 April 2010] ICJ Rep, 128 (finding that a highly informal
} 
and whether they can be said to have agreed to something under international law. Klabbers convincingly coins the idea of "presumptive law" arguing that "in international affairs, emanations that are of normative significance and that are based on some form of consent by the relevant actor, must be presumed to be legally binding". To rebut this presumption parties must then provide clear language or other contextual elements that demonstrate that the instrument is not binding or not part of international law. ${ }^{173}$

That said, a lot of the new transnational activity described above does not fall under the traditional sources of international law set out in Article 38 of the ICJ Statute, e.g. because there is sufficient evidence that the state parties did not intend to agree under international law ${ }^{174}$ or because the actors involved (be it public agencies or private actors) do not have the capacity to create international law in the first place. ${ }^{175}$ However, the mere fact that something falls on the non-law side does not preclude that it is regulated by law or needs justification under law. Especially where a non-law instrument still has legal effects (and may thereby restrict freedom) such justification or regulation by law becomes crucial. As a result, even where a soft law or informal law instrument is not as such "international law", it could still (i) have legal effects, and/or (ii) be subject to legal constraints (or be regulated by law), be it under international law, domestic law or the rules internal to the mechanism where the instrument was created.

\section{b. The emergence of procedural meta-norms for any normative restriction on freedom}

When an instrument does not meet the threshold of law (i.e. traditional international law before an international tribunal), serious thought must be given to what legal effects it may still have and how to control these effects. Checks and balances are needed which should involve an examination of (i) the source, respectability and authority of the norm creating body, (ii) transparency, openness and neutrality in the norm's procedural elaboration and (iii) the substantive quality, consistency and overall acceptance (consensus) of the norm. Schepel refers to these collectively as rules of "procedural integrity" adding that such control by international tribunals (e.g. the WTO) over outside norms "exercises an upward pull on the work of private standardizers". ${ }^{176}$ Scott and Sturm have referred to this judicial control as "courts as

understanding, the so-called CARU minutes, between the Foreign Ministers of Uruguay and Argentina is binding under international law: 'Whatever its specific designation and in whatever instrument it may have been recorded (the CARU minutes), this "understanding" is binding on the Parties, to the extent that they have consented to it and must be observed by them in good faith'; likewise, at 149, the ICJ treats a 2005 press communiqué between Argentina and Uruguay, laying down a procedural obligation, as a binding agreement, just not having the contents that Uruguay claimed it had).

${ }^{173}$ Klabbers chapter 10, OUP book. D'Aspremont supra note 59 goes a step further and suggests to drop "intent" as the law-ascertainment criterion altogether and to replace it with a more formal criterion focused on the instrumentum or form used to memorialize agreement (the so-called "container") rather than on what parties intended or agreed on (the negotium or so-called "content"), more specifically "by a systemic use of written linguistic indicators".

${ }^{174}$ See, for example, the International Forum of Sovereign Wealth Funds: "... the Forum shall not be a formal supranational authority and its work shall not carry any legal force" (Kuwait Declaration: Establishment of the International Forum of Sovereign Wealth Funds, 6 April 2009, available at: http://www.iwg-swf.org/mis/kuwaitdec.htm), discussed in Malathouni, Chapter 7, TOAEP book.

${ }^{175}$ As the ISO puts it: "the agency neither regulates, nor creates laws" (quoted in Geraets and Duquet, Chapter 11, TOAEP book).

${ }^{176}$ See Schepel, Chapter 16, OUP book (lamenting that the refusal by the WTO Appellate Body to engage in such control in EC - Sardines "treats standards as mere facts, which makes for terrible legal policy". In support: S. Bernstein and E. Hannah, Non-State Global 
catalysts". ${ }^{177}$ Krisch's theory of post-national pluralism is grounded in the choices and allegiances of individuals and gives different weight to norms depending on their "public autonomy credentials", an assessment that includes some of the elements listed above. ${ }^{178}$ These three criteria - referring to authority, procedure and substance -- also link back to the very definition of IN-LAW as we have defined it, involving new actors, processes and outputs as well as to the benchmark of "thick consensus" described above which is slowly emerging as a "code of good practice" in the standard-setting world and beyond. ${ }^{179}$

The legal techniques that can then be used by international tribunals to refer to these outside norms - e.g. Basel or ISO standards, ICH or IBA guidelines - could be reliance on them as facts or treaty interpretation, e.g. interpreting a treaty with reference to these outside norms as reflecting a "good faith" interpretation, "ordinary meaning" (if a general dictionary can provide ordinary meaning, why not a standard or guideline developed by experts in the specific field?), "subsequent agreement" or "subsequent practice" (both, however, focusing on "agreement" or practice establishing "the agreement" of state parties, not other actors) or other "relevant rules of international law" (although the latter would pre-suppose that the outside norms are actually part of international law). ${ }^{180}$ Certain treaties may also directly or indirectly incorporate or make reference to such outside norms or standards (as the SPS and TBT agreements do at the WTO referring, for example, to Codex and ISO standards). ${ }^{181}$ This, of course, facilitates making a bridge to them.

When it comes to the check and balances to be applied to these outside norms - the procedural meta-norms related to authority, procedure and substance referred to earlier - on what legal basis could those be relied on? An argument could be made that they are emerging as norms of customary international law or general principles of law, traditional sources that are referred to in Article 38 of the ICJ Statute. Note, indeed, that pursuant to Article 38, "conventions" must be recognized by "states" thereby apparently excluding new actors. ${ }^{182}$ In contrast, for "custom" and "general principles" there is no explicit reference to "states". Custom is defined as "evidence of a general practice accepted as law", without specifying who must have accepted this practice as "law". General principles of law, in turn, must be "recognized by civilized nations", where the word "nation" could be understood more broadly than central state actors alone. Both custom and general principles thereby leave the door

Standard Setting and the WTO: legitimacy and the need for regulatory space', (2008) 11 Journal of International Economic Law 575.

${ }_{177}$ See supra note 120.

178 Krisch, supra note 125, at 101 ("the weight of a collective's claim will follow from the strength of its social grounding, of the participatory practices that support it as well as the plausibility of its attempt to balance inclusiveness and particularity").

${ }_{179}$ See the ISEAL Code of Good Practice for Setting Standards, available at

http://www.isealalliance.org/code. This Code of Good Practice is imposed on ISEAL's membership, including the Forest Stewardship Council, the Rainforest Alliance, the Marine Stewardship Council, the Fair Trade Labelling Organization, and others. As Schepel, Chapter 16, OUP book, notes: "These procedures were not adopted spontaneously out of a collective civic awakening: they have evolved in response to demands by public authorities and courts". ${ }^{180}$ See Articles 31(1) to 31(3) of the Vienna Convention. See also Article 31(4): "A special meaning [which could draw on outside norms or standards] shall be given to a term if it is established that the parties so intended".

${ }^{181}$ See also the UNESCO International Convention against Doping in Sport which expressly refers to the World Anti-Doping Agency and its Code, and requires that States align their antidoping legislation with the WADC principles, discussed in Cassini, Chapter 18, OUP book.

${ }_{182}$ But see Article 3 of the Vienna Convention on the Law of Treaties which does refer to other subjects, discussed supra note 63. 
open to new actors as well as new types of processes and outputs. ${ }^{183}$ Checks and balances have been developing internally within each normative sub-system (be it the ISO, ICH or Basel Committee). Reference has been made to reflexive governance ${ }^{184}$, the self-generated internal law of administration ${ }^{185}$ or a variety of system-specific deontologies which replace morals with professional standards. ${ }^{186}$ Over time, convergence around certain procedural meta-norms that apply across the board may emerge. This will take time and we may not have reached that stage yet. More experimentation, trial and error are needed. This is normal. Ladeur describes, for example, how domestic German administrative law developed not starting from general codes imposed by the legislator or courts. ${ }^{187}$ Rather, principles emerged from the practice within administrative agencies. The same process is occurring at the international level. Time will tell whether procedural meta-norms will arise and on what legal basis they will then be enforced. ${ }^{188}$ It may well be that they will be codified in a treaty or other standard or agreement. They could also develop through the case law or jurisprudence of international courts and tribunals ${ }^{189}$, or emerge as general principles of law or even custom. The attraction of such procedural meta-principles is that, as procedural rules, they may attract universal support. That way, international law may continue to play its "neutral" role. ${ }^{190}$ More than thirty years ago, Herbert Simon has pointed out that, from the perspective of decision theory, when it comes to highly complex problems or constellations it is impossible to achieve absolute agreement of all actors involved through rational deliberation as there is always more dissent and non-knowledge than available knowledge and agreement. As a result, the only viable kind of rationality is, in his words, "procedural rationality", that is, a rational and agreed-upon way to organize a decision-making process. ${ }^{191}$

Tribunals may then consider or not consider a norm and give it varying degrees of weight the way they evaluate, weigh and refer to other "legal facts" (be it in the process of establishing facts, legal interpretation or application of law to facts). Ultimately, however, this may lead to a paradox. For formal or traditional

\footnotetext{
${ }^{183}$ And as discussed supra note 63 also the Vienna Convention leaves the door open to agreements between new subjects of international law.

${ }^{184}$ See Olivier De Schutter and Jacques Lenoble (eds.), Reflexive Governance, Redefining the Public Interest in a Pluralistic World, Hart Publishing, Oxford, 2010.

${ }_{185}$ Ladeur, Evolution, supra note 187 at 17; Mashaw supra note 187 at 1461.

186 Niklas Luhmann, Die Moral der Gesellschaft, Herausgegeben von Detlef Horster, Frankfurt, Suhrkamp, 2008 at $163 \mathrm{ff}$.

${ }^{187}$ Karl-Heinz Ladeur, The Evolution of General Administrative Law and the Emergence of Postmodern Administrative Law, Osgoode Hall Law School, Research Paper Series, Research Paper No. 16/2011, 2011 at 38. For a similar view on US administrative law, see Jerry Mashaw, Federal Administration and Administrative Law in the Gilded Age", 119 Yale L.J. 1362 (2010), at 1361-2.
}

${ }^{188}$ For a critical view, in the specific context of universal principles of administrative law, see Carol Harlow, Global Administrative Law: The Quest for Principles and Values 17 EJIL (2006) 187-214 at 187.

${ }^{189}$ Article 38(1)(d) refers to "judicial decisions" and even to "the teachings of the most highly qualified publicists of the various nations" as "subsidiary means for the determination of rules of law". On the role of national courts, see See E Benvenisti and G Downs, 'National Courts, Domestic Democracy, and the Evolution of International Law' (2009) 20 EJIL 59; and B Kingsbury, 'Weighing Global Regulatory Decisions in National Courts' in Acta Juridica (2009).

190 As strongly advocated by, for example, Prosper Weil, Toward Relative Normativity of International Law, 77 AJIL (1983) 413. For a different, value-laden account, see Emmanuelle Jouannet, Le droit international libéral-providence, Une histoire du droti international, Ed. Bruylant, 2011.

${ }^{191}$ Herbert Simon, Rationality as process and as product of thought, 68 American Economic Association Review (1978) 1. See also Niklas Luhmann, Legitimation durch Verfahren, Neuwied-Berlin: Luchterhand, 1969. 
international law to arise "thin" state consent suffices (as discussed above, the validation rules of international law are agnostic when it comes to process, actors involved, instrument or substance). In contrast, for other norms or standards to merely have legal effects, the above criteria of a "thick consensus" must be met, examining both the source (authority) and the procedural and substantive quality of the norm. The test for "mere" legal effects is thereby stricter than the test for actual "law". If one believes in the full, legitimizing effect of state consent, this may not be a paradox at all: whereas legal effects do not require consent by each state (and therefore need justification on other grounds), for something to be international law, the stop-clause of state consent is, at least under current international law standards, both a sufficient and necessary condition. Another way to alleviate this tension is, of course, to gradually move to a test of "thick consensus" for both formal law and other norms or standards with merely legal effects. Yet, for that to happen a fundamental reassessment of traditional international law would be called for: a shift from "thin consent" to "thick consensus". ${ }^{192}$

\section{c. A few examples}

A good, recent example of how traditional international law is grappling with novel forms of governance and standard-setting can be found in the US - Tuna I/ dispute recently decided at the WTO. ${ }^{193}$ In that dispute, Mexico challenged the labeling requirements imposed by the United States in respect of tuna products and when such products could be labeled as "dolphin-safe". Whereas the US adopted a unilateral standard ("no setting of fishing nets on dolphins" tout court), Mexico claimed that tuna meeting its standard ("no mortality or serious injury of dolphins") should also get the US "dolphin-safe" label. Mexico's standard was, moreover, based on the Agreement on the International Dolphin Conservation Program (AIDCP) and resolutions adopted under the AIDCP, to which Mexico, the US and 12 other countries are a party. A core question that arose in this dispute was whether the AIDCP labeling requirements could be regarded as an "international standard" on which the US should base its national standard pursuant to Article 2.4 of the WTO Agreement on Technical Barriers to Trade (TBT). The test employed by the WTO panel and Appellate Body in this respect goes in the direction of the "thick consensus" test discussed above. This is the case, importantly, even though the instruments under examination (in particular the AIDCP treaty) were ultimately traditional international law instruments. With reference to definitions found in the standardization world (ISO/IEC Guide 2:1991) and a non-binding decision adopted by the WTO's TBT Committee ${ }^{194}$, the panel imposed the following requirements for

\footnotetext{
192 Some weighing of actual international law along «thick consensus » requirements may already be possible under, for example, Article 31.3(c) of the Vienna Convention which calls upon a treaty interpreter to " take into account ", together with context, " any relevant rules of international law applicable in the relations between the parties ». Whereas such reference is limited to " rules of international law ", the qualifiers that they must only be " taken into account ", be "relevant " and "applicable in the relations between the parties " leaves flexibility for tribunals to apply «thick consensus » type checks and balances.

193 Panel and Appellate Body Reports on United States - Measures Concerning the Importation, Marketing and Sale of Tuna and Tuna Products, WT/DS381/R and AB/R, adopted 13 June 2012. Another example, though not as of yet the object of WTO dispute settlement, is the debate on the position of private standards, especially in the area of food safety, within the WTO: see generally Jan Wouters and Dylan Geraets, 'Private Food Standards and the World Trade Organization: Some Legal Considerations', 11:3 World Trade Review 2012, 479-489.

194 Decision Of The Committee On Principles For The Development Of International Standards, Guides And Recommendations With Relation To Articles 2, 5 And Annex 3 Of The Agreement, G/TBT/1/Rev.9, p. 37-9, pursuant to which (in para. 1) six "principles and procedures should be observed ... to ensure transparency, openness, impartiality and
} 
something to be an "international standard". The document must be (1) a "standard" that was (2) "adopted by an international standardizing/standards organization" and (3) "made available to the public". For the document to be a standard, it must (i) "be established by consensus", (ii) "be approved by a recognized body", and (iii) "provide for common and repeated use, rules, guidelines or characteristics for activities or their results aimed at the achievement of the optimum degree of order in a given context". An international standardizing organization, in turn, is (i) a "body that has recognized activities in standardization" and (ii) "whose membership is open to the relevant national body from every country", in casu, every WTO member (although this ensures inclusiveness of all national bodies; it does not ensure participation by other stakeholders). Made available to the public, finally, includes respect for certain transparency procedures concerning elaboration, dissemination and implementation.

Based on this definition, the WTO panel found that the AIDCP labelling requirements do constitute an "international standard". The Appellate Body, in contrast, though not disagreeing with the panel's definition, was not convinced that membership in the AIDCP was open to the relevant bodies of at least all WTO Members. It was, in particular, not persuaded that being invited to join the AIDCP is a mere "formality" since to invite new members consensus of all AIDCP parties is required. ${ }^{195}$ The United States pointed out, for example, that although all states whose vessels fish for tuna in the area were eligible, WTO members with an interest other than fishing such as consumer or conservation interests were ineligible to become parties. ${ }^{196}$ The Appellate Body agreed that "an international standardizing body must not privilege any particular interests in the development of international standards" and underscored "the imperative that international standardizing bodies ensure representative participation and transparency in the development of international standards". ${ }^{197}$

For something to be an "international standard", relevant in WTO adjudication, both source (authority) and procedural and substantive requirements must therefore be met (crucial elements of the "thick consensus" benchmark discussed above). These requirements are fundamentally different from what is required for the establishment of international law, including the WTO treaty itself ("thin consent"). In particular, where the WTO requires "consent" (as in veto power for each WTO member), "consensus" in the TBT/international standards sense is defined (in ISO/IEC Guide 2) with reference not only to who ultimately must agree/has veto rights (more lenient than "thin consent") but also with reference to process, who must be heard and how must disagreements be weighed (stricter than "thin consent"). ${ }^{198}$ In addition, if one were to apply the WTO's test of what constitutes an "international body" to the WTO itself, the WTO would fail as it is not "open" to all countries but subject to rigorous accession requirements and veto by all existing WTO members.

In the investment context as well, norms enacted by new actors and in new forms play an increasing role. Tribunals frequently refer to and apply, for example, rules developed by the privately run International Bar Association (IBA) (e.g. the Rules on the Taking of Evidence in International Commercial Arbitration and the Guidelines on

consensus, effectiveness and relevance, coherence, and to address the concerns of developing countries".

${ }_{195}$ Ibi.d, para. 398.

${ }^{196}$ Ibid., para. 383.

197 lbid., paras. 379 and 384.

198 Thereby disagreeing with an earlier Appellate Body decision in EC-Sardines finding that consensus adoption is not a requirement for an "international standard" in the sense of TBT Article 2.4, see supra note 176. The Appellate Body in US - Tuna I/ left this issue open. 
Conflicts of Interest in International Arbitration). ${ }^{199}$ These rules do not have the force of law, have never been consented to by states and are normally not incorporated in the arbitration rules by the disputing parties. Instead, they were developed by experts and the epistemic community of global arbitration. Questions have been raised about their legitimacy and whether such instruments are "a tool by which the arbitration elite maintains its power and control over international arbitration". ${ }^{200}$ One solution is to subject these instruments to the source (authority), procedural and substantive elements of the "thick consensus" test discussed earlier. Along similar lines, Kaufmann-Kohler has suggested to "integrate users in the process of soft law creation ["generally weaker parties that are not commercial or business players, but rather consumers, athletes, employees and the like"], thereby extending the consultation beyond the service providers (arbitral institutions, counsel, arbitrators) presently involved". ${ }^{201}$ In addition to such inclusiveness, "thick consensus" would also test (i) the source and authority of the norm creating body, (ii) transparency, openness and neutrality in the norm's procedural elaboration and (iii) the substantive quality, consistency and overall acceptance (consensus) of the norm.

Interestingly, however, a recent arbitration tribunal, acting not in the field of investment arbitration, but under the UN Convention on the Law of the Sea, refused to refer to the same IBA Guidelines on Conflicts of Interest. It did so explicitly relying on the "thin consent" paradigm discussed earlier (rather than applying the idea of "thick consensus" which the WTO panel on US - Tuna II opted for). ${ }^{202}$ This arbitration tribunal was, of course, bound by the applicable law under the Law of the Sea Convention (whereas the WTO panel in US - Tuna I/ had an explicit mandate to refer to "international standards" under the TBT Agreement). That said, as discussed earlier, also this UNCLOS tribunal could have derived some guidance from the IBA Guidelines if only as relevant facts or as normative guidance to interpret or shed light on the applicable UNCLOS provisions the state parties agreed on, at least to the extent these Guidelines emanate from a respected authority, were elaborated in an open and fair process and have over the years attracted support amounting to a consensus in the arbitral community (the "thick consensus" benchmark).

\section{CONCLUSION}

There is strong evidence that the field of international law is in a process of stagnation, both quantitatively (number of treaties) and qualitatively (thin state consent followed by domestic rubber-stamping by Parliament or Congress). New, alternative forms of cross-border cooperation have emerged and gained prominence especially since the 2000s. Not surprisingly, as insiders looking at new players joining the scene, international lawyers have focused their attention on whether these new forms are legitimate or even law in the first place. What has been neglected is an internal reflection on what these new forms tell us about traditional international law. This paper challenges the assumption that traditional international law is, by definition, legitimate and new forms must be presumed not to be. Instead, it points at "thin state consent" as the increasingly flimsy basis of traditional international law and an emerging, normatively superior benchmark of "thick

\footnotetext{
${ }^{199}$ Another example can be found in ICS v. Argentina, where the tribunal, for purposes of interpreting the dispute settlement provisions of the UK-Argentina BIT, referred to nonbinding World Bank guidelines.

${ }^{200}$ Anna Di Robilant, Genealogies of Soft Law (2006) 54 Am. J. Comp. L. 549.

201 Gabrielle Kaufman-Kohler, Soft Law in International Arbitration: Codification and Normativity, 1 Journal of International Dispute Settlement (2010), 283-299, at 299.

${ }^{202}$ The Republic of Mauritius v. The UK of Great Brittan and Northern Ireland, Reasoned Decision on Challenge, 30 November 2011, available at http://www.pcacpa.org/upload/files/Reasoned\%20Decision\%20on\%20Challenge.PDF (italics added) at 165 and 167.
} 
stakeholder consensus" that underlies many of the new forms of cooperation. Our point is not that new forms are without problems (some need, in particular, more input by external stakeholders and more domestic oversight), just that new and traditional must be continuously kept in check and, if so, that both can offer legitimate forms of cooperation. In the long term, we may see a transformation of international law towards the "thick consensus" benchmark, emancipating (but also controlling) new actors, new processes and new types of normative outputs. History teaches us that we have seen other, equally dramatic changes in the international legal order since the Middle Ages. In the short to medium term, the core questions will be to define what is international law and how does or should it interact with new forms of cooperation. This paper argues that even non-law can have legal effects (and, if so, must be regulated by law), and that new forms of cooperation (assuming they are not already law) can be given legal effect already today by international courts, in particular when they meet the "thick stakeholder consensus" benchmark or triple barreled meta-norm of procedural integrity axed on (i) the source, respectability, and authority of the norm creating body, (ii) the transparency, openness, and neutrality in the norm's procedural elaboration, and (iii) the substantive quality, consistency, and overall acceptance (consensus) and objectivity of the norm. If correct, this assessment has consequences for the entire discipline of international law, including law school teaching. Why is it, for example, that in the face of the stagnation of international law, law schools continue to teach only traditional international law and leave new forms of cooperation to international relations scholars? If we want to keep both the field and its students sociologically relevant we will need to look beyond the four corners of traditional actors, processes and outputs. 
The Leuven Centre for Global Governance Studies is an interdisciplinary research centre of the Humanities and Social Sciences recognized as a Centre of Excellence at the Katholieke Universiteit Leuven. It hosts researchers from law, economics, political science, history, philosophy and area studies. The Centre carries out and supports interdisciplinary research on globalization, governance processes and multilateralism, with a particular focus on the following areas: (i) the European Union and global governance; (ii) trade and sustainable development; (iii) peace and security; (iv) human rights, democracy and rule of law; (v) non-state actors and global governance; (vi) space governance; and (vii) comparative federalism. It hosts the InBev Baillet-Latour Chair EU-China and the Leuven India Focus.

In addition to its fundamental research activities the Centre carries out independent applied research and offers innovative policy advice and solutions to policy-makers.

In full recognition of the complex issues involved, the Centre approaches global governance from a multilevel and multi-actor perspective. The multi-level governance perspective takes the interactions between the various levels of governance (international, European, national, subnational, local) into account, with a particular emphasis on the multifaceted interactions between the United Nations System, the World Trade Organization, the European Union and other regional organizations/actors in global multilateral governance. The multi-actors perspective pertains to the roles and interactions of various actors at different governance levels, which includes public authorities, formal and informal international institutions, business enterprises and non-governmental organizations.

For more information, please visit the website www.globalgovernancestudies.eu

Leuven Centre for Global Governance Studies

Huis De Dorlodot, Deberiotstraat 34, 3000 Leuven, Belgium

Tel. ++321632 8725

Fax ++3216373547

info@ggs.kuleuven.be

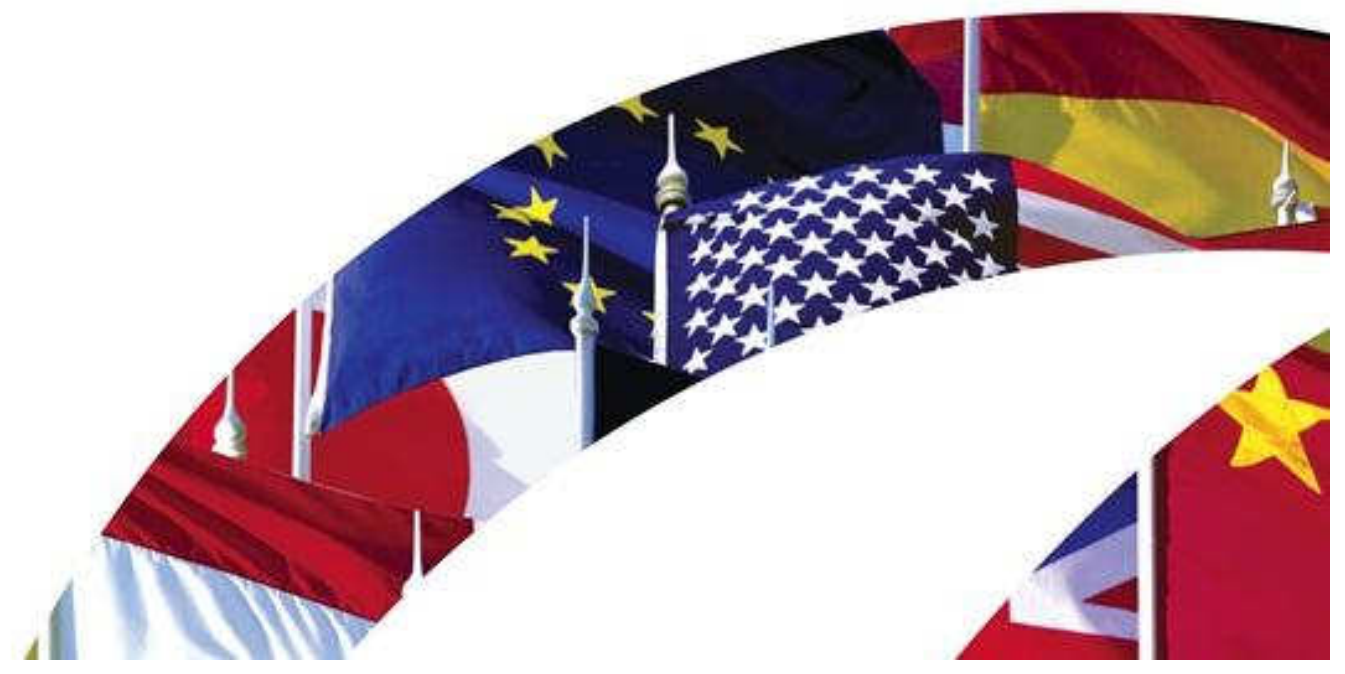

